\title{
Modelling Siberian river runoff — implications for contaminant transport in the Arctic Ocean
}

\author{
I.H. Harms ${ }^{\text {a, * }}$, M.J. Karcher ${ }^{\text {b,1 }}$, D. Dethleff ${ }^{c}$ \\ a Institut für Meereskunde,Universität Hamburg, Troplowitzstasse. 7, 22529, Hamburg, Germany \\ ${ }^{\mathrm{b}}$ Bundesamt für Seeschiffahrt und Hydrographie, Bernhard-Nocht-Strasse 78, 20359, Hamburg, Germany \\ ${ }^{\mathrm{c}}$ GEOMAR-Forschungszentrum, Wischhofstrasse 1-3, 24148, Kiel, Germany
}

Received 9 February 1999; accepted 12 October 1999

\begin{abstract}
This model study investigates the role of Siberian river runoff for the transport of possible river contaminants in the Arctic Ocean. Three-dimensional coupled ice-ocean-models of different horizontal resolution are applied to simulate the dispersion of river water from Ob, Yenisei and Lena. These Siberian rivers are supposed to be important sources for various contaminants. The relevant processes which are considered in this study include the dispersion of dissolved or suspended contaminants in the water column and the transport of contaminated particles, incorporated into drifting sea ice.

Circulation model results from both spatial scales explain the main pathways and transit times of Siberian river water in the Arctic Ocean. Kara Sea river water clearly dominates in the Siberian branch of the Transpolar Drift, while the Lena water dominates in the Canadian branch. River water concentrations in Nares Strait, Canadian Archipelago, are similar to those in the northern Fram Strait. Special emphasis is given to the seasonal variability of the river plume in the Kara Sea. Particle tracking simulations on the regional scale illustrate that $\mathrm{Ob}$ and Yenisei tracers behave differently. Yenisei tracers leave the Kara Sea quite fast towards the Arctic Ocean or the Laptev Sea, but Ob tracers spread also in the southern Kara Sea, in particular at lower levels.

A comparison of simulated freezing rates and particle concentrations in Siberian coastal waters suggests that during autumn, the incorporation of particles into freezing sea ice near the estuaries of Ob and Yenisei is very likely. Simulated ice trajectories, started close to the Lena river delta easily reach the multi-year Transpolar Drift within one winter. Ice trajectories from $\mathrm{Ob}$ and Yenisei estuaries, however, mostly drift towards the Barents Sea where the ice melts close to Svalbard. The model study confirms that contaminant transport through sediment-laden sea ice offers a short and effective pathway for pollutant transport from Siberian rivers to the Barents and Nordic Seas. C) 2000 Elsevier Science B.V. All rights reserved.
\end{abstract}

Keywords: Arctic; river runoff; contaminants; modelling

\footnotetext{
* Corresponding author. Tel.: +49-40-42838-4206; fax: +4940-5605-724.

E-mail address: harms@ifm.uni-hamburg.de (I.H. Harms).

${ }^{1}$ Present affiliation: Alfred-Wegener-Institut für Polar- und Meeresforschung, Columbusstrasse, 27568, Bremerhaven.
}

\section{Introduction}

The paper deals with the fate of possible contaminants in the Arctic Ocean. Numerical circulation models of different scale are used to study pathways 
and transit times of tracers from the Siberian rivers $\mathrm{Ob}$, Yenisei and Lena. Two model domains were considered: a large scale model of the Arctic Ocean and a regional scale model for the shelves of the Kara Sea. The models differ in their numerical and physical approach; however, both models use the same meteorological forcing data. The forcing data consist of climatological monthly mean atmospheric data.

Following an introduction of relevant processes and pathways, Section 2 is dedicated to regional scale dispersion studies in the Kara Sea, where the $\mathrm{Ob}$ and Yenisei estuaries are located. Section 3 describes the fate of river water on the large scale domain, i.e. the whole Arctic Ocean and the northern North Atlantic. Section 4 combines both scales by investigating the possibility of sediment or particulate matter transport by sea ice. Finally, Section 5 summarises our findings with respect to Arctic river contaminants.

\subsection{Processes and pathways}

The Arctic rivers Ob, Yenisei and Lena drain huge land areas in Siberia and Russia. They gather large amounts of water and particulate material and transport them over long distances. The rivers are supposed to be key sources for various contaminants. The catchment areas include many diffuse sources such as agricultural runoff loaded with pesticides. Discharges of municipal and industrial sewage from heavily populated and industrialised areas south of the Arctic contribute to the contamination load. Other polluting activities are mining and oil and gas exploitation. Two nuclear fuel reprocessing plants, Mayak and Tomsk, enter the drainage areas of the $\mathrm{Ob}$, the third one, Krasnoyarsk, goes directly into the Yenisei (AMAP, 1998; NATO, 1998).

In general, contaminants in the marine environment have to be divided into two classes: dissolved contaminants, i.e. substances which are redistributed by the flow field more or less passively, and particles or particle reactive substances which tend to attach to particles or suspended material in the water column. Most of the pollutants of concern are in fact particle-reactive like heavy metals such as lead, iron, copper and cadmium, organochlorides like PCBs and
DDTs and certain radionuclides (Pfirman et al., 1995).

The total annual amount of freshwater input to the Arctic Ocean by Ob, Yenisei and Lena equals roughly $1500 \mathrm{~km}^{3}$ /year (Fig. 1) of which $80 \%$ is discharged in spring (May-June) (Pavlov and Pfirman, 1995). This results in peak discharge rates of more than $100,000 \mathrm{~m}^{3} / \mathrm{s}$ (e.g. Yenisei). The strong seasonal variance in freshwater runoff influences the input of dissolved and particulate matter from the rivers. The peak release of suspended matter by the rivers might even be more pronounced than the freshwater signal itself because the spring break-up of river ice is usually a very turbulent event (Pfirman et al., 1995). In total, the Arctic rivers carry about 221 million tons of sediment per year into the Arctic Ocean of which $\mathrm{Ob}$ and Yenisei alone deliver 22.4 million tons into the Kara Sea (AMAP, 1998).

The Arctic Ocean interior is characterised by a strong vertical haline stratification. Due to its low density, the major portion of the inflowing river water from the shelves stays in the upper tens of meters. Dissolved contaminants may reach deeper water layers only through vertical mixing or convective overturning in well-mixed shelf areas. The situation is different for particle bound contaminants. Up to $90 \%$ of the suspended organic matter settle in the estuaries in contrast to $20-40 \%$ of riverine dissolved organic components (Stein, 1989). The particles may be resuspended due to strong bottom currents or even due to convection. Upward transport of particles in the water column makes them available for further dispersion (Schlosser et al., 1995).

Sea ice plays a special role in the transport of contaminants in the Arctic (Pfirman et al., 1995). The ice gathers material from the atmosphere, by overflowing river water in spring or through freezing of bottom sediments ("anchor ice") (AMAP, 1998). A frequently described process is the incorporation of sediments or particles during ice formation. The coastal areas of the Arctic Shelves are characterised by recurrent open water between fast and drifting ice, which are driven by offshore winds. These "flaw leads" produce large amounts of new ice through the mechanism of leeward advection (Martin and Cavalieri, 1989; Dethleff et al, 1998b). Turbulent mixing and thermohaline convection enhance resuspension of fine-grained material. Through the process of 


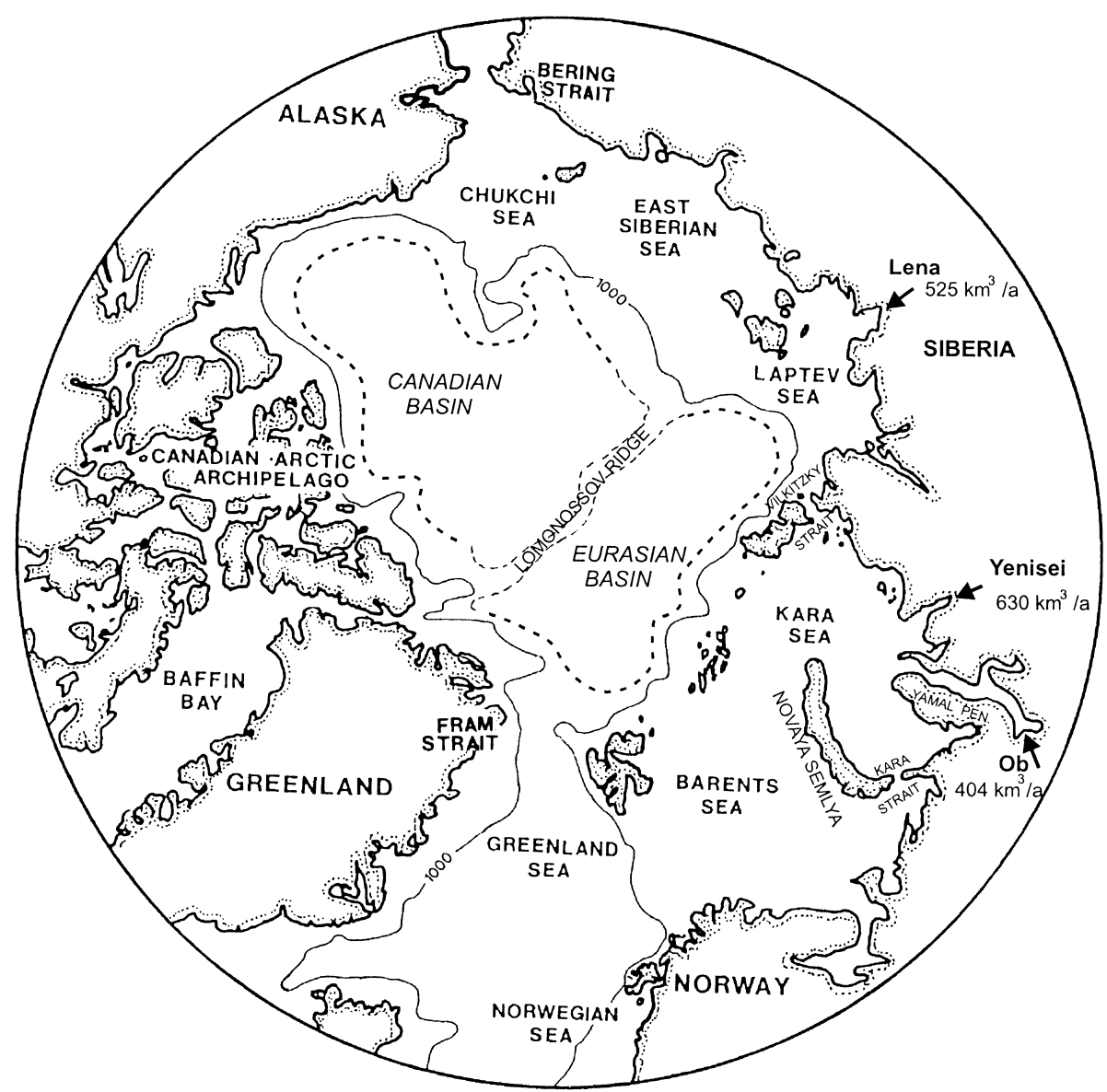

Fig. 1. Topography of the Arctic Ocean.

"suspension freezing", material will be filtered out of the water column and incorporated into the newly formed grease ice (Reimnitz et al., 1993; Dethleff et al., 1994).

Considerable amounts of sediment or particulate material is exported from shallow Siberian Shelves by the Transpolar Ice Drift towards Fram Strait (Nürnberg et al., 1994). Once incorporated into the ice cover, the potentially contaminated material will join the Transpolar Drift and may enter the northern North Atlantic. The Arctic sea ice melts most extensively in the Greenland Sea, along the marginal ice zones. Because this is usually a region of intense biological activity, the pollutants which are released directly into surface waters may easily enter the food chain. Moreover, the melt period often coincides with the spring bloom of biological activity, increasing the potential for biological uptake of contaminants. The transport of particulate material by sea ice may therefore play an important role in long-range redistribution of contaminants in the Arctic and North Atlantic (Pfirman et al., 1995).

\section{Regional scale studies}

The regional scale studies are focussed on the Kara Sea, in particular on the river runoff from $\mathrm{Ob}$ and Yenisei (c.f. Fig. 1). The used Kara Sea Model is described only very briefly. A detailed description 
of the model configuration, the model forcing and the results is given in Harms and Karcher (1999). More general information on the numerical model including applications to other Arctic Shelf Seas can be found in Stronach et al. (1993), Harms (1997a) and Harms (1997b).

\subsection{Model configuration}

The hydrodynamic model of the Kara Sea is based on the Hamburg Shelf Ocean Model (HAMSOM) which is a 3-D, baroclinic circulation model, developed at the Institute of Marine Research (University Hamburg) for investigations of shelf sea processes (Backhaus, 1985). The model is based on non-linear primitive equations of motion, invoking the hydrostatic approximation and the equation of continuity. The circulation model is coupled to a thermodynamic and dynamic sea ice model which calculates space- and time-dependent variations of ice thickness and ice compactness. The basic configuration follows Hibler (1979), Semtner (1976) and Parkinson and Washington (1979). The ice movement is calculated with a free-drift algorithm that accounts for advection of ice thickness and compactness due to wind and water stress. In shallow regions (depth $<20 \mathrm{~m}$ ), the ice movement is reduced or even stopped in order to simulate land-fast ice.

The Kara Sea Model is forced with daily mean meteorological data which is interpolated from a monthly mean climatological $\mathrm{ECMWF}^{2}$-data set (Trenberth et al., 1989; Aukrust and Oberhuber, 1995). The wind stress at the ice or water surface follows a second order approach using different wind drag coefficients for water and ice. Surface heat fluxes at the ocean-ice-atmosphere interfaces are calculated on the basis of air temperature, cloud cover and relative humidity with standard bulk formulae (Maykut, 1986). The oceanic gain and loss of heat is used to determine the sea surface temperature which in turn affects the ice formation and salt fluxes.

The model accounts for the dominant $\mathrm{M}_{2}$-tidal constituent. The Barents Sea inflow through the Kara

\footnotetext{
${ }^{2}$ ECMWF: European Center for Medium Range Weather Forecast, Reading, UK.
}

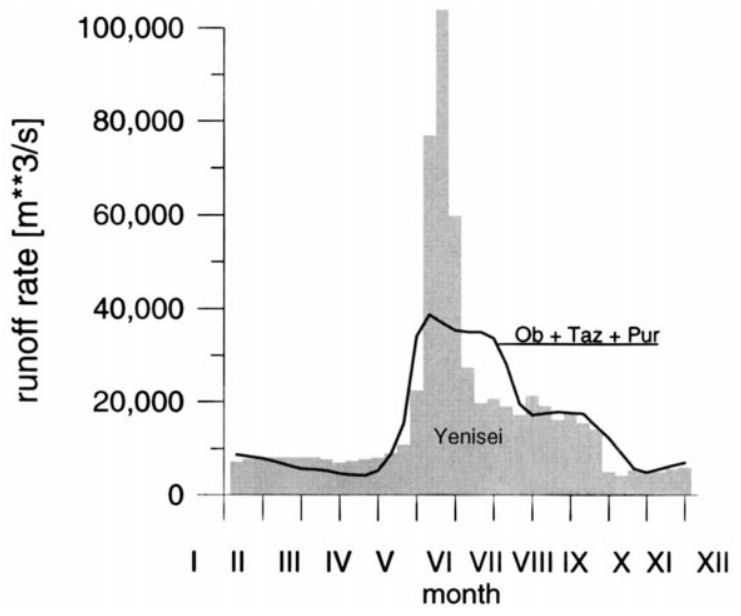

Fig. 2. Applied 10-day mean river runoff from $\mathrm{Ob}(+$ tributaries Taz and Pur) and Yenisei.

Strait is of major importance because it brings heat and salt into the Kara Sea. To account for these effects, the net in- or outflow is prescribed as 10-day mean volume fluxes. The maximum transport rate into the Kara Sea is $0.65 \mathrm{~Sv}$ during the first half of January. In summer, when northerly winds prevail, the inflow is reduced, showing a slight net outflow $(-0.07 \mathrm{~Sv})$ towards the Barents Sea in July and August. The mean inflow averaged over one year is $0.3 \mathrm{~Sv}$. This is in good agreement with measurements (Pavlov and Pfirman, 1995).

River runoff rates from $\mathrm{Ob}$, Yenisei and Pyasina are prescribed as 10-day mean volume fluxes in $\mathrm{m}^{3} / \mathrm{s}$ (Fig. 2). The Ob tributaries, Taz and Pur, are included in the $\mathrm{Ob}$ runoff. The salinity of the rivers, at the point where they enter the model domain, was set to 5 psu whereas the temperature was prescribed depending on the season. Highest river temperature in August was set to $3.8^{\circ} \mathrm{C}$, the lowest during winter at the freezing point $\left(-0.3^{\circ} \mathrm{C}\right)$.

A three-dimensional advection scheme based on the advection-diffusion transport equation is applied in order to treat the salinity and water temperature as a free "prognostic" variable that is not constrained by given data. The same Eulerian transport algorithm is used for passive tracers. Like for temperatures and salinity, the vertical diffusion of matter (i.e. the vertical eddy diffusivity coefficient) depends on 
stratification and vertical current shear. Horizontal eddy diffusion is neglected because of numerical diffusion stemming from the advection scheme. A Langrangian transport routine is used for particle tracking of passive tracers in river water. In this routine, horizontal diffusion is parameterised through the Monte Carlo method which implies a random walk of particles.

\subsection{The Kara Sea circulation}

The applied meteorological ECMWF data set describes a cyclic, climatological year. This forcing is used to generate a cyclic stationary flow field that reproduces the seasonal variability of circulation and hydrography in the Kara Sea. The cyclic stationary state is reached after approximately 3 years spin-up time.

The most dominant feature of the simulated climatological year is a pronounced seasonal variability of currents and hydrography, caused by the wind field, the freshwater runoff and the ice formation. There is no typical 'Kara Sea circulation' that prevails throughout the year. Our recently obtained circulation fields have led to a revised view of the "classical" Kara Sea circulation presented by, e.g. Pavlov et al. (1993) or Pavlov and Pfirman (1995). This holds in particular for a frequently cited cyclonic current structure in the southern Kara Sea which was not supported either by our model simulations nor by observations (Krosshavn et al., 1998). Based on recent model results, two circulation schemes were identified (Harms and Karcher, 1999):

- The spring and summer situation (Fig. 3a) is characterised by weak anticyclonic wind fields and strong river runoff. The dominating wind direction is from north to north-east. The general circulation pattern in the Kara Sea is anticyclonic with strong currents very close to the river estuaries.

- In autumn and winter (Fig. 3b), the circulation is almost reversed and strongly intensified, showing
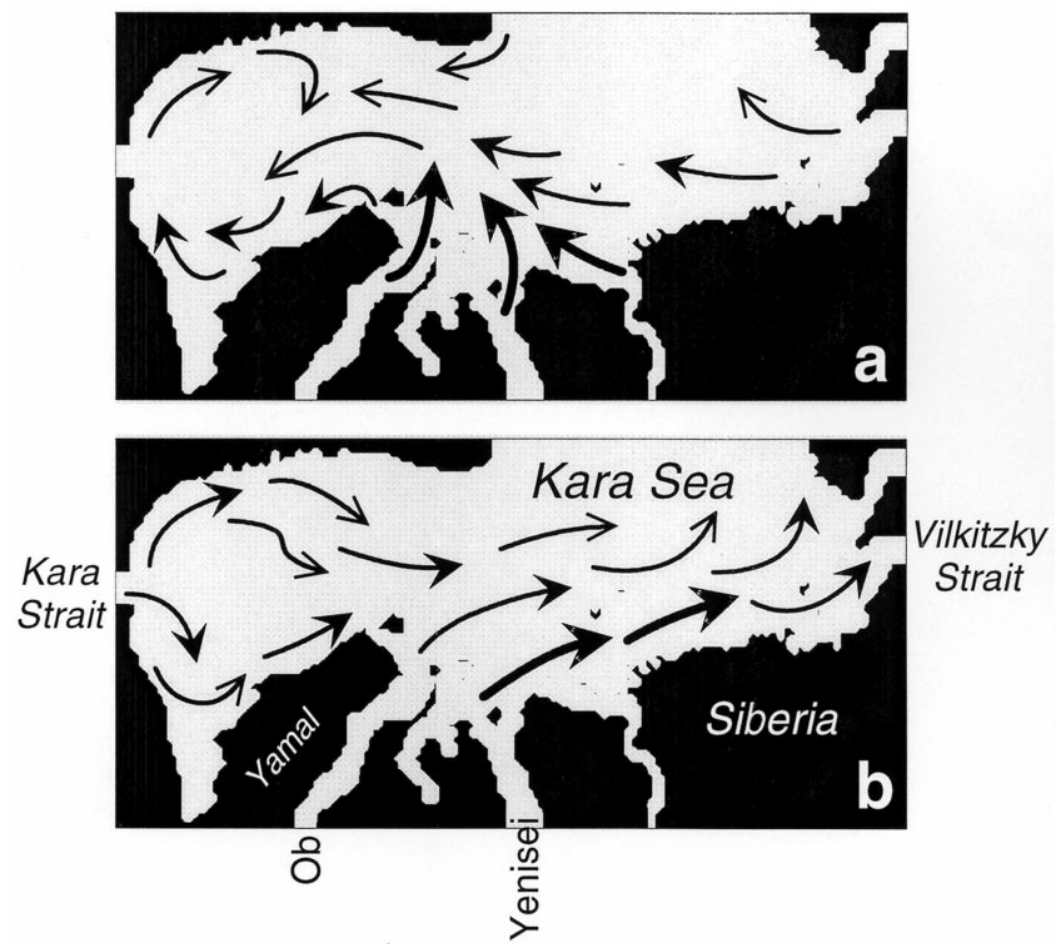

Fig. 3. Simplified sketch of the simulated surface circulation; a: spring/summer, b: autumn/winter. 
a general flushing from south-west to north-east. Strong cyclonic winds from south-west and a large extent of the river plume cause a very pronounced coastal current at the Siberian coast.

It has to be mentioned, that this description is strongly simplified. However, these two circulation schemes explain most of the seasonal variability in river tracer dispersion.

\subsection{Dispersion of river water in the Kara Sea}

The dispersion of river water in the Kara Sea is studied with tracer concentrations, using the Eulerian advection-diffusion equation. Based on the cyclic stationary flow field, the river water is initialised with a $100[\%]$ concentration whereas the ambient Kara Sea is initialised with $0[\%]$ concentration. The dispersion of the river water was traced for 8 years, until a cyclic stationary state was achieved.

The shape and extent of the surface river plume is depicted in Fig. 4. In spite of strong variability in river runoff rates and wind forcing, the seasonal variation in the extent of the plume is surprisingly small. Even in winter, when runoff rates are very low, the area with a river water fraction exceeding $5 \%$ is roughly comparable to the summer situation. However, looking at higher percentage rates of river water in the Kara Sea, seasonal differences become more obvious. Significant seasonal variability is visible north of the estuaries where the area of river water fraction exceeding $50 \%$ is much broader in summer than in winter.

The surface river plume is also quite variable in the north-east of the Kara Sea where the export of river water takes place. The export is high in autumn and winter, when the river water forms an eastward flowing coastal current along the Siberian shore. In that time of the year, most of the river water leave the Kara Sea through the eastern open boundary (i.e. the Vilkitzky Strait) to the Laptev Sea. In spring and summer, however, the export through Vilkitzky Strait decreases significantly. It is even blocked in July and August when north-easterly winds drive an inflow from the Laptev Sea into the Kara Sea. During these months, the eastern part of the river plume is de-

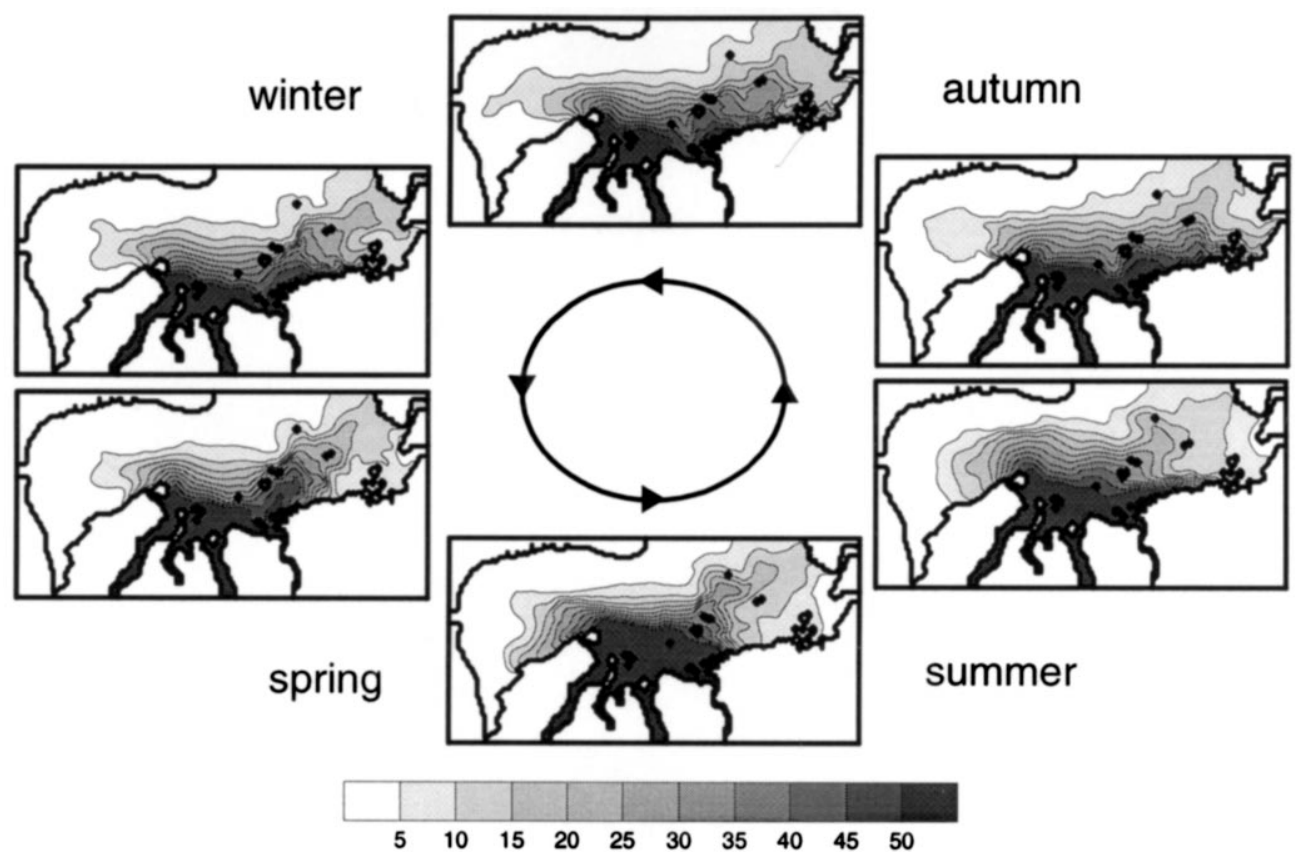

Fig. 4. Simulated $\mathrm{Ob}$ and Yenisei river water fraction [\%] at the surface, within a cyclic, climatological year. 


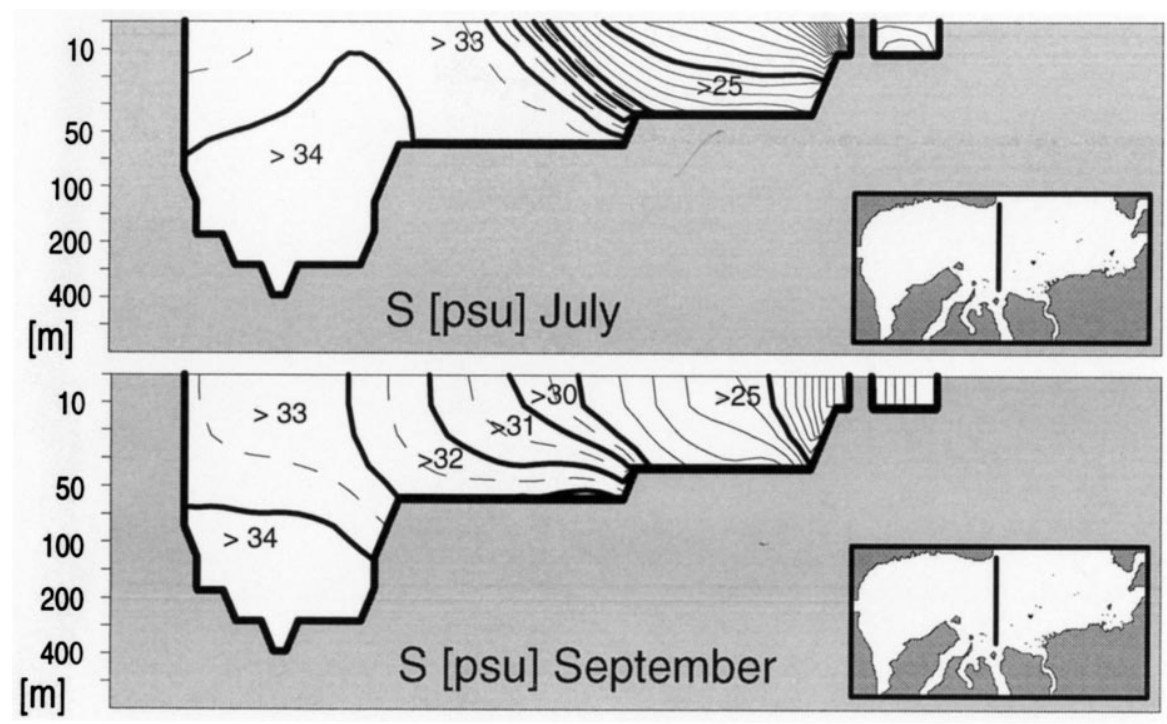

Fig. 5. Simulated vertical sections (see inset) through the Kara Sea in summer and autumn, showing the haline stratification at the Siberian shore.

tached from the Siberian coast and most of the river water export goes through the northern boundary, between Novaya Semlya and Severnaya Semlya, towards the Arctic Ocean.

The freshwater from the rivers produces a very pronounced haline stratification that can be observed in late summer/autumn when the freshwater plume has its largest extent. Vertical density gradients in this area (Fig. 5) are most pronounced in the upper $50 \mathrm{~m}$ causing strong baroclinic pressure gradients (Harms and Karcher, 1999). This stratification influences not only the circulation but also the vertical exchange of water masses and other dissolved substances. The surface circulation is partly uncoupled from the flow at lower levels which affects the drift of river tracers at different depth horizons. This effect is demonstrated in the following section.

\subsection{Particle tracking of the river outflow}

Circulation modelling of the Kara Sea shows that the seasonal variability of currents in the $\mathrm{Ob}$ or Yenisei estuary is quite large (Harms and Karcher, 1999). The current speeds are highest during spring and summer when the runoff is large and decrease significantly in autumn and winter. There is also a strong variability in current directions in the estuaries. Whereas in spring the currents are directed north-westward into the central Kara Sea, the late summer currents in the estuaries point to eastward directions.

The influence of seasonally varying currents and runoff rates on the time-dependent evolution of river water dispersion in the Kara Sea is studied with particle tracking methods. Passive tracers were continuously released in different depth horizons in the $\mathrm{Ob}$ or Yenisei estuary, mainly during peak runoff (May/June/July).

Our results show, that the tracer dispersion depends very much on the tracer depth. Comparing the particle clouds of $\mathrm{Ob}$ and Yenisei against each other, it is obvious that at the surface, both river tracers behave quite similarly (Fig. 6, left and right). In both river esturies, the spring tracer dispersion is directed mainly north-westward into the central Kara Sea. Some $\mathrm{Ob}$ tracers even go westward and reach the west coast of the Yamal peninsula. From August/ September onward, the wind directions change and the tracers turn eastward. At this stage, however, large parts of the particle cloud have already reached the central Kara Sea. In the following months, the 

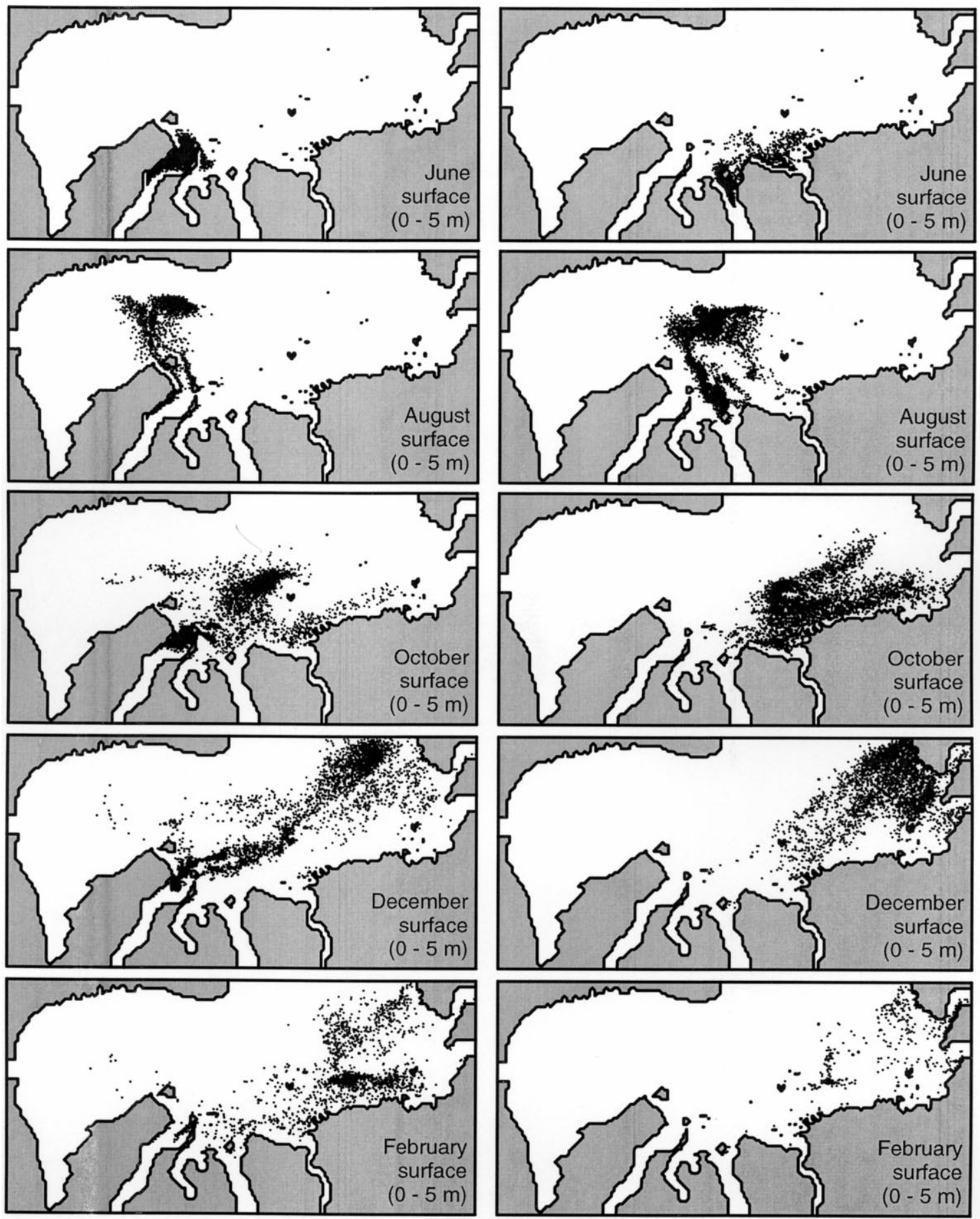

Fig. 6. Simulated dispersion of $\mathrm{Ob}$ (left) and Yenisei (right) tracers at the surface, following a continuous release in May, June and July. 
river tracers are pushed back to the Siberian shore. The $\mathrm{Ob}$ tracers remain more offshore than Yenisei tracers and leave the model domain also northward, between Novaya Semlya and Severnaya Semlya. The Yenisei tracers are much more confined to the Siberian coast and leave to a large extent towards the Laptev Sea.
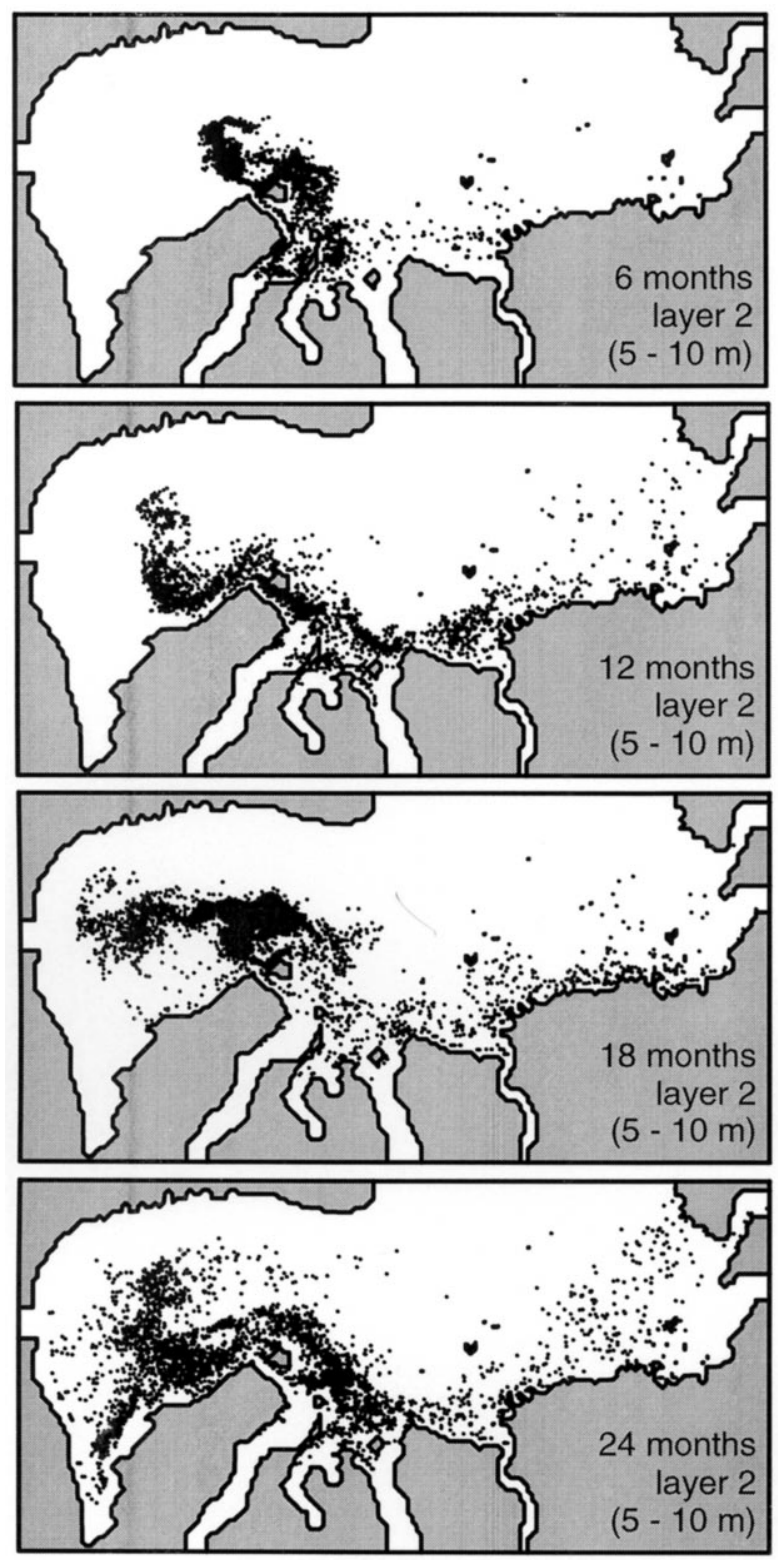

Fig. 7. Simulated dispersion of Ob (left) and Yenisei (right) tracers in layer 2 (5-10 m), following a continuous release in May, June and July.
At lower levels, the tracer dispersion but also the resulting transit times show significant differences between $\mathrm{Ob}$ and Yenisei. Whereas large parts of surface river tracers usually need less than 1 year to leave the model domain, lower level tracers might circulate for several years in the central Kara Sea (Fig. 7). This holds in particular for 'deeper' $\mathrm{Ob}$
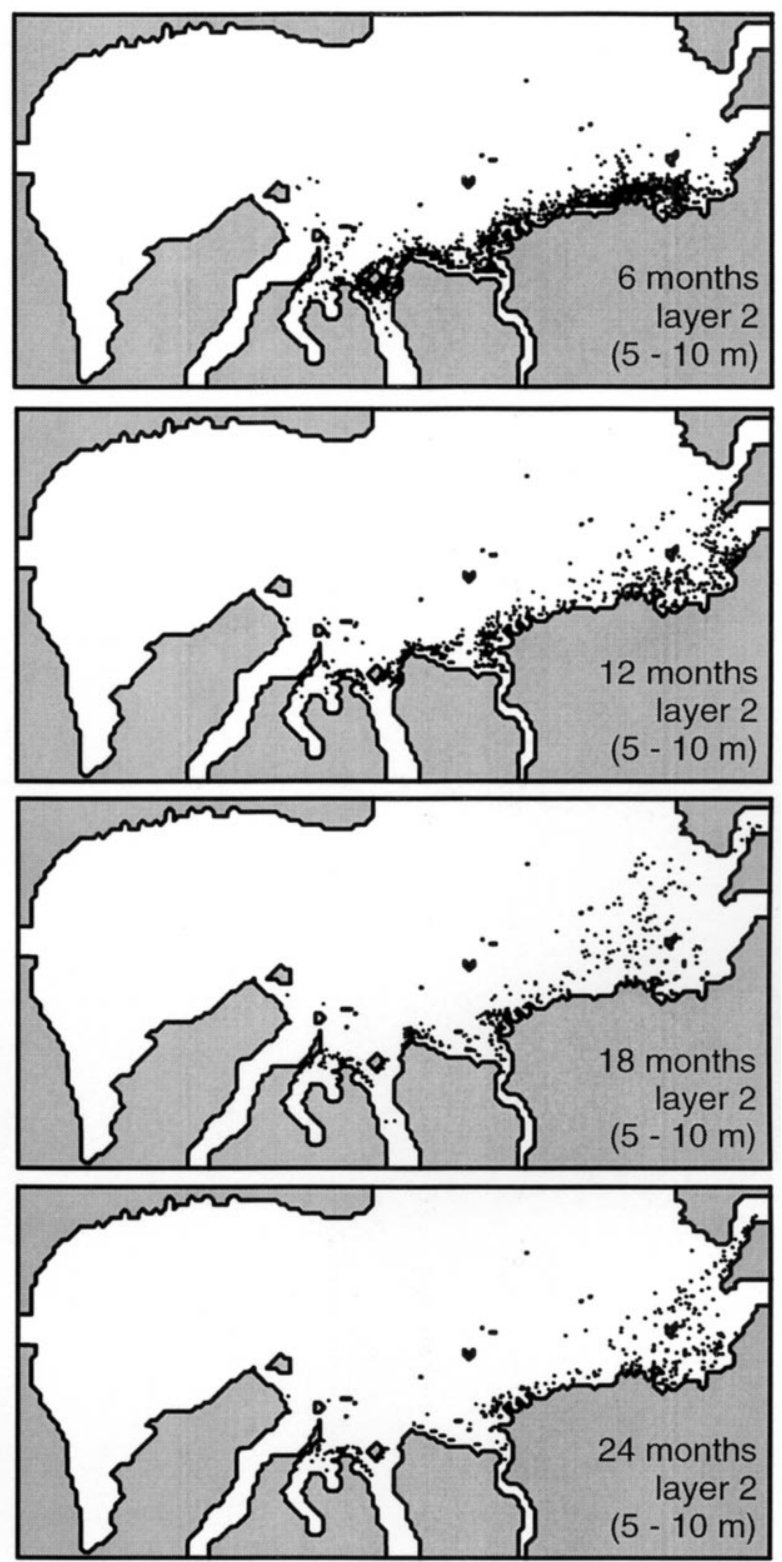
tracers that spread to a large extent in the southwestern Kara Sea. This is definitely not the case for Yenisei tracers at the same depth level. These tracers leave the region quite fast ( $<2$ years) mainly through Vilkitzky Strait towards the Laptev Sea.

\subsection{Discussion}

A validation of the simulated river tracer dispersion is difficult, first of all because direct observations are scarce or unpublished, and secondly because the application of climatological forcing fields in prognostic model simulations leads to 'artificial' results that do not reflect a real or observed situation. Concerning the Kara Sea circulation, we found very good agreement between our model results and available observations in several areas (Harms and Karcher, 1999). In particular, laboratory modelling results seem to support the numerical circulation results in several points (McClimans, 1997).

An important model result is the 'straight-lined' dispersion of the spring freshwater signal from $\mathrm{Ob}$ and Yenisei to the north-west, into the central Kara Sea. This contradicts the classical view of estuarine processes in the northern hemisphere which implies a more or less strong deflection to the right. The reason for this untypical intrusion is the considerable intensity of the runoff during spring but also the corresponding wind field. When we compared these model results with historical and recent observations, we found good agreement between both. A significant dispersion of river water to the north-west has already been suggested by Nansen (1902). It was later confirmed by Milligan (1969) and was also found by Johnson et al. (1997). A recently published satellite image supports the model findings by showing warm river water north or even west of the Yamal peninsula (NATO, 1998; Krosshavn et al., 1998).

Following this pronounced spring intrusion, the large extent of the river plume in the central Kara Sea diminishes in August/September, when the winds change and large amounts of freshwater are pushed back to the Siberian shore. A coastal current develops that prevails throughout autumn and winter. This leads to seasonally varying export rates of river water. Whereas in winter the export is enhanced and mostly through Vilkitzky Strait into the Laptev Sea, the summer export of river water is much lower and mainly northward, towards the Arctic Eurasian basin.

The particle tracking studies revealed, that at lower levels, the $\mathrm{Ob}$ and Yenisei tracers behave very differently. Yenisei tracers usually leave the model domain quite fast to the east but $\mathrm{Ob}$ tracers spread to a large extent also in the south-western Kara Sea. A reason for the abundance of $\mathrm{Ob}$ tracers in the southern Kara Sea is probably the current variability at the Yamal coast. North-eastward currents at the west coast of Yamal prevail only during autumn and winter, but in spring and summer, the flow is mainly south-westward (Harms and Karcher, 1999). Ob tracers that have reached the north coast of Yamal may be caught by these flows and transported into the southern Kara Sea.

Yenisei tracers at lower levels are much slower than the corresponding surface tracers which leave the model region in less than 1 year. The reason for longer transit times at lower levels is a south-westward undercurrent that flows at $5-10 \mathrm{~cm} / \mathrm{s}$ along the Siberian shore, in the opposite direction to the surface flow (Harms and Karcher, 1999). In our model simulations, the main driving force for this flow is a strong baroclinic pressure gradient, stemming from the sloping isopycnals in the vertical density stratification (c.f. Fig. 5). The baroclinic pressure gradient opposes the barotropic one, which is determined by the sea surface elevation. This situation is most likely in late summer, when the river plume has fully established and the wind and the coastal sea level still reflect the summer situation. The Siberian undercurrent is therefore strongest in late summer and weakest or absent in late winter or spring. Recent observations and modelling efforts support our findings: vertical current shear was also found at current meter moorings deployed close to the $\mathrm{Ob}$ and Yenisei estuaries in autumn (Johnson et al., 1997) and also in laboratory model studies by McClimans (1997).

\section{Large scale studies}

Calculations on the large scale are performed with an Arctic version of a coupled ice-ocean model OPYC, based on a development by Oberhuber 
(1993). Details of the numerical and physical features of the model are discussed in Aukrust and Oberhuber (1995) and in Holland et al. (1996). The current version is applied to the ventilation of the interior Arctic Ocean as described in Karcher and Oberhuber (1999).

\subsection{Model configuration}

The Arctic ocean model has 14 layers of constant potential density, whose thickness and tracer concentrations are variable. It is coupled with a mixed-layer model at the surface and a dynamic/thermodynamic snow /ice model. The horizontal grid size is approximately $50 \mathrm{~km}$ on a rotated spherical grid. The Bering Strait and the southern boundary are open and forced by monthly mean temperature and salinity fields from Levitus (1982) and by sea surface height data from a global version of OPYC (Kauker and Ober- huber, 1999). While the yearly mean inflow through the Bering Strait is forced to give the observed level of $0.8 \mathrm{~Sv}$, the other straits may develop freely. The sea surface salinity is restored to observed summer and winter data from Gorshkov (1980) for the Arctic Ocean and monthly mean data from Levitus (1982) for the rest of the model domain. The time step for ice and ocean models is half a day. For the horizontal eddy viscosity, a harmonic formulation is used in combination with a diffusion coefficient which depends on grid size and deformation radius. The diffusion coefficient for salt, temperature and tracers is $250 \mathrm{~m}^{2} \mathrm{~s}^{-1}$. The restoring time scale for the sea surface salinity to observed values is set to 12 days.

Heat fluxes at the sea surface are derived from parameterisations (Oberhuber, 1993) that employ observed atmospheric temperatures (ECMWF, 1988). The model is driven with monthly mean ECMWF winds and atmospheric data from the period 1985-

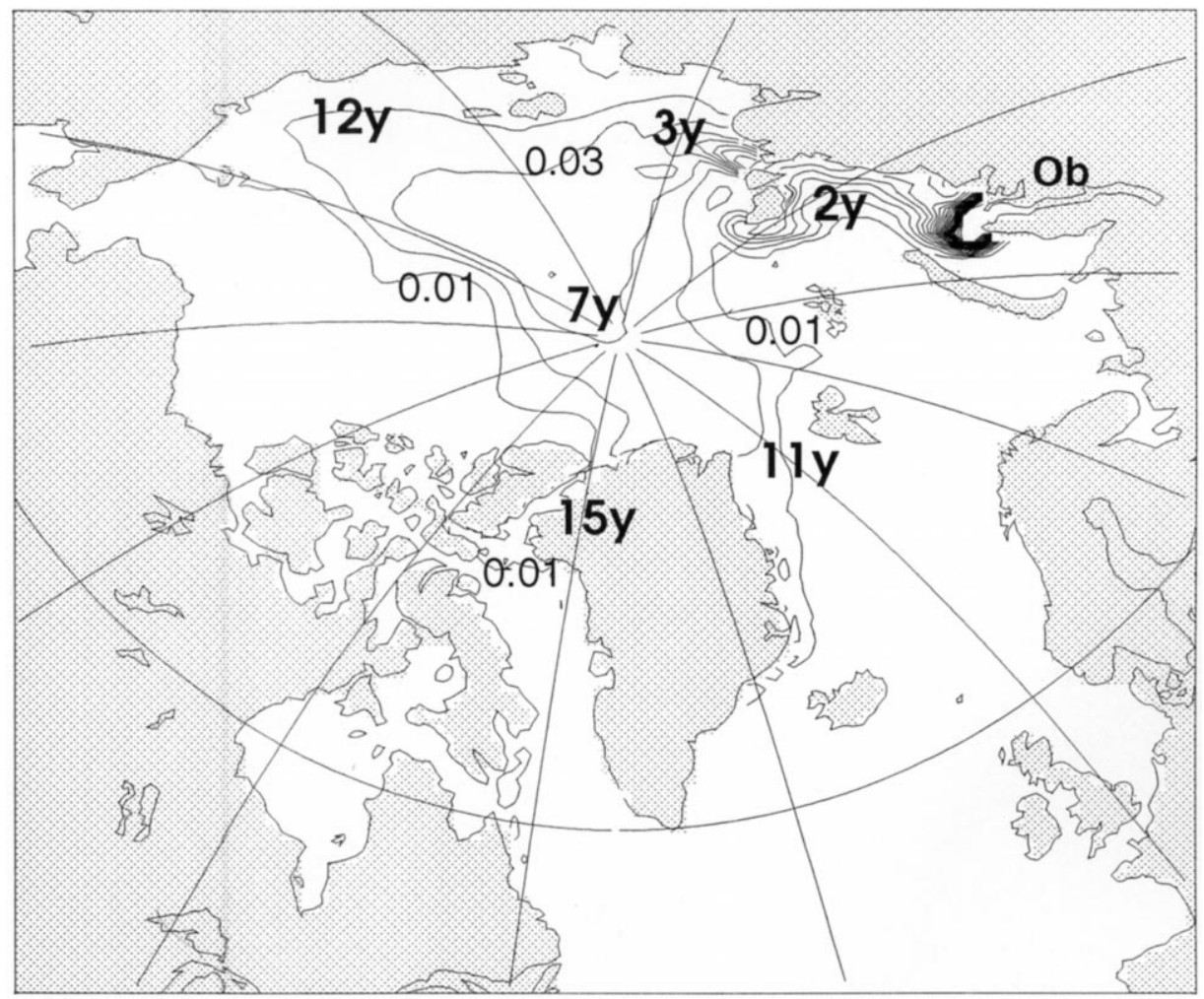

Fig. 8. Fraction of river water introduced as a passive tracer in the Ob estuary after 30 years of dispersion. The bold numbers depict the advective time scale for the river water tracer in years. 
1990 (Trenberth et al., 1989; Aukrust and Oberhuber, 1995). Monthly means of cloud cover and humidity are taken from (Wright, 1988).

After 35 years, when a stable seasonal cycle in the ice and the upper ocean circulation is achieved, the integration is stopped. This seasonal cycle of the model flow is used to drive a tracer transport model, which is based on an Eulerian advective/diffusive scheme equivalent to the one used for temperature and salinity in the ocean model. In addition, the seasonal cycle of ice drift and circulation is used to calculate Lagrangian ice trajectories.

\subsection{Dispersion of river water in the Arctic Ocean}

The ocean model does not have an explicit inflow of river water. Instead, the inflow of freshwater on the shelves is realised via a restoring of the sea surface salinity to the observed salinity data from Gorshkov (1980). A passive tracer is injected in proportion to the observed monthly mean river runoff data (Gorshkov, 1980) at the river mouths of Lena, $\mathrm{Ob}$ and Yenisei. Three minor rivers discharging into the same estuaries are added to the three major rivers. The yearly runoff rate amounts to 560 $\mathrm{km}^{3}$ /year for Lena and Oljenok, $563 \mathrm{~km}^{3}$ /year for $\mathrm{Ob}$ and Pur and $689 \mathrm{~km}^{3} /$ year for Yenisei and Pjasina. Since the river water tracers are passive, they can as well be viewed as plumes of contaminants.

The river water from $\mathrm{Ob}$ and Yenisei stays on the Kara Sea shelf for the first two years after release (Figs. 8 and 9). The bulk of this water subsequently enters the Laptev Sea via the Vilkitsky Strait in the third year, while a smaller fraction moves northward. This agrees with results from Frank (1996) who

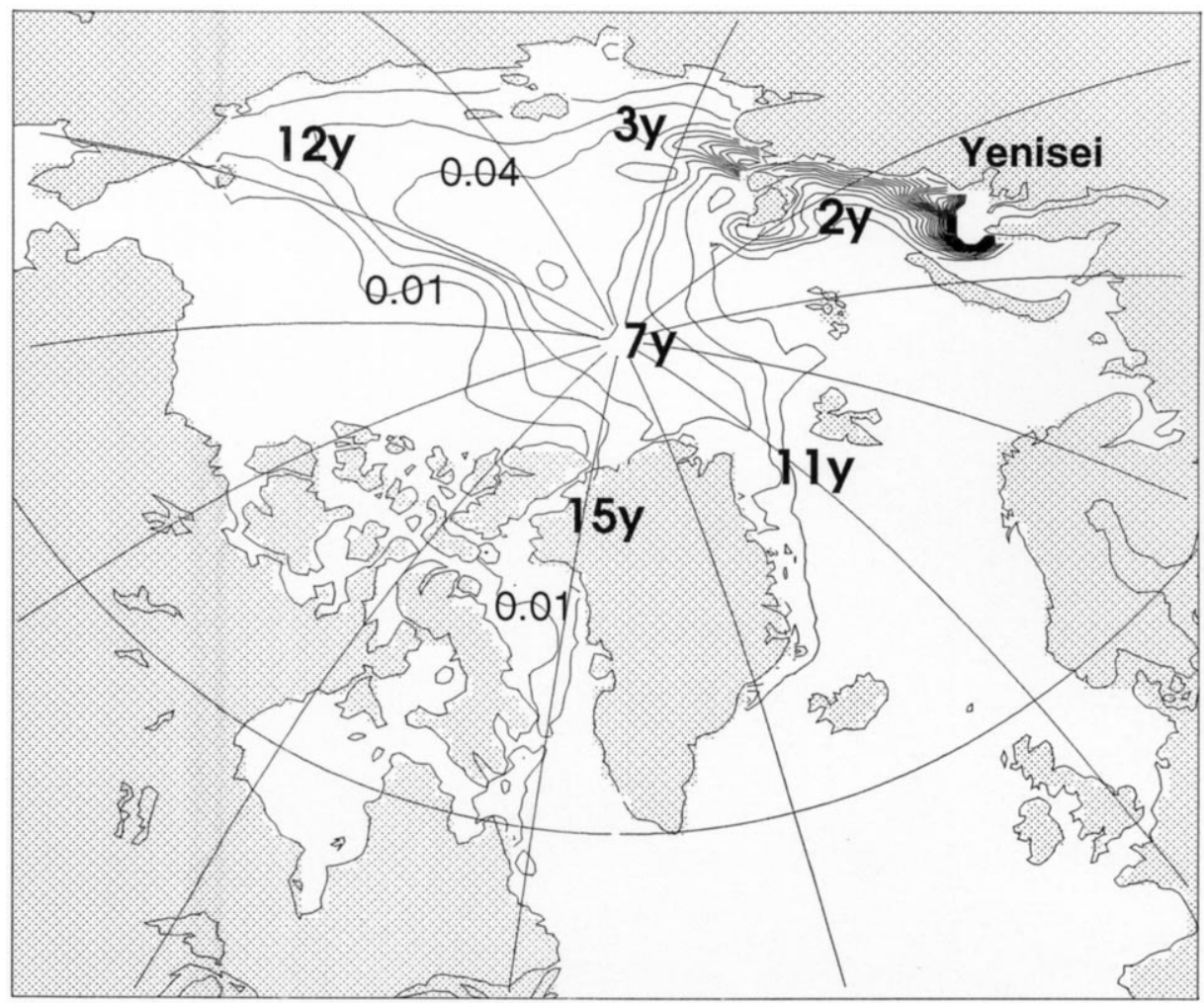

Fig. 9. As before, but with tracers introduced in the Yenisei estuary. 
derived river water fractions from $\mathrm{d}^{18} \mathrm{O}$ measurements. The advection of a large fraction of Kara Sea river water into the Laptev Sea before passing further into the central Arctic Ocean is also indicated by measurements of total dissolved inorganic carbon (Olsson and Anderson, 1997). Leaving the Laptev Sea, the waters of $\mathrm{Ob}$ and Yenisei split. One part turns northward along the Lomonossov Ridge to reach the North Pole with the Transpolar Drift after about 7 years, another part continues eastward. It enters the East Siberian Sea, where a maximum extent of the river water from the Kara Sea is achieved after 14 years. The Transpolar branch arrives at Fram Strait 11 years after starting at the river mouths and after 15 years $\mathrm{Ob}$ and Yenisei waters start entering Nares Strait in the Canadian Archipelago. About 20 years after start, both river tracer distributions are in a seasonal cyclic state. Whereas the path and the advective time scale of both tracers are very similar, the concentrations of the Yenisei water are about $3-4 \%$ and of $\mathrm{Ob}$ water $2-3 \%$ in the western Eurasian Basin.

The movement of tracers originating from the Lena river contrasts the $\mathrm{Ob}$ and Yenisei tracers, which exhibit very similar on the large scale (Fig. 10). The seasonal variability of all three river water distributions is rather small on the Arctic scale. However, the Lena river plume has its maximum extension in spring, when river water fractions as high as $30 \%$ reach the Severnaya Semlya islands. After 2 years, the Lena river water leaves the Laptev Sea shelf. Part of the water proceeds with the shelf current eastward, as far as the New Siberian Islands. Here, the Lena river water makes up about $10 \%$ of the surface water, all year round. The other part feeds directly into the Transpolar Drift reaching the North Pole after 9 years, the Canadian Archipelago and Fram Strait after 15 years.

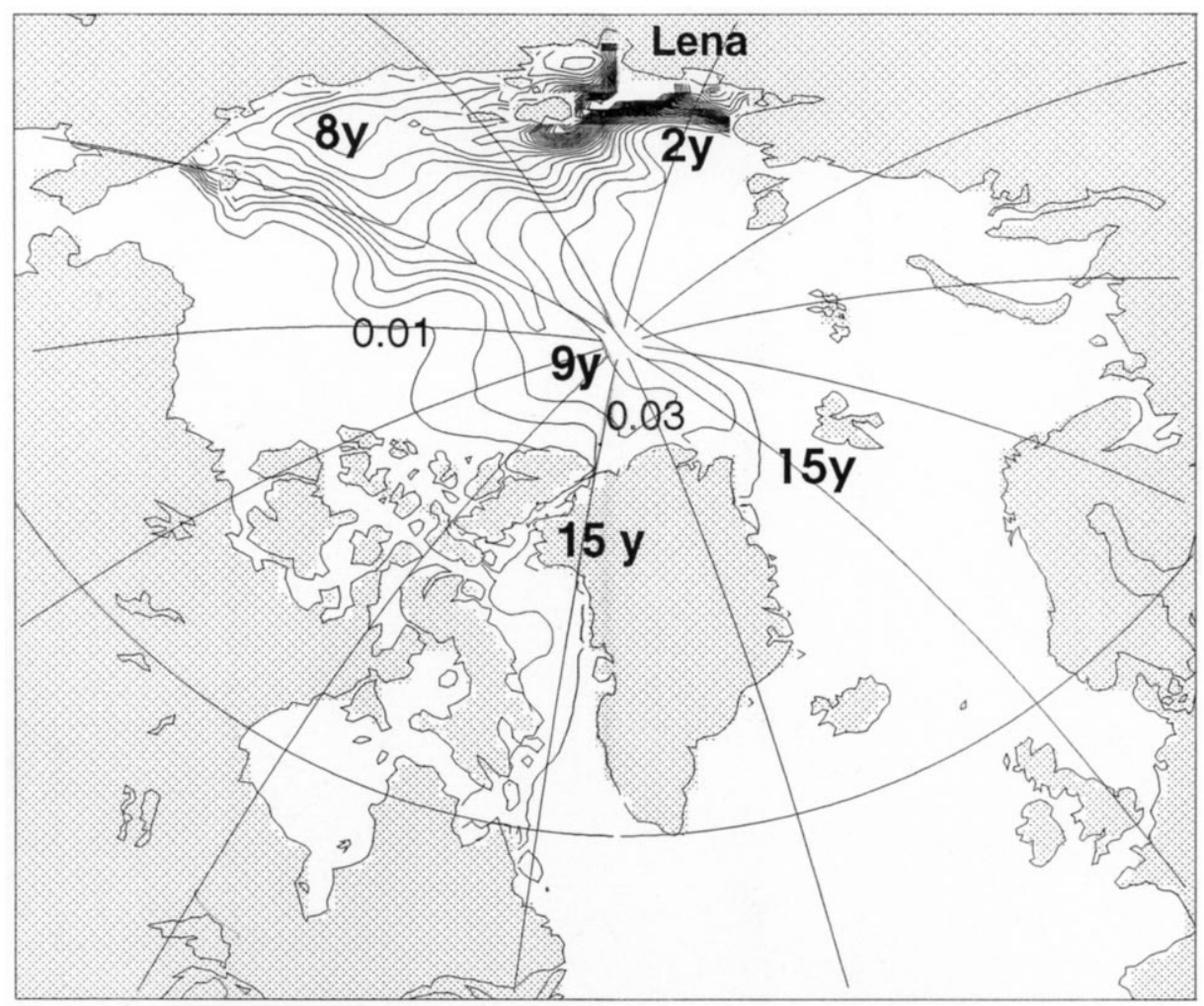

Fig. 10. As before, but with tracers introduced in the Lena estuary. 
Schlosser et al. (1994) estimated a mean residence time for river water on the shelves of $3.5 \pm 1.5$ years from Tritium/Helium measurements. Three and a half years have also been estimated by Pavlov and Pfirman (1995). The mean residence time of river water in the polar surface layer of the Eurasian Basin is computed to 4.1-6.5 years by Frank (1996). Taking into consideration that those estimates make use of data from the whole Eurasian Basin including the shelves, the model results and the estimates from the data are in good agreement.

It is remarkable that in the current model simulation the concentrations of Lena river tracers leaving the Arctic Ocean via the Canadian Archipelago are almost twice as high as in the East Greenland Current, Fram Strait. Contrary to that, the $\mathrm{Ob}$ and Yenisei concentrations are more evenly distributed in both throughflow areas. As discussed in Karcher and Oberhuber (1999), the current model run exhibits a small Beaufort Gyre and a Transpolar Drift consisting of several branches, all of which show positions above or beyond the Lomonossov Ridge. The modelled river water, e.g. from the Kara Sea, moves with water originating from the Atlantic. Such a dominance of the Atlantic inflow, extending as far eastward as the Mendeleev Ridge, appears to be typical for the early 1990s. This situation which can be inferred from hydrographic and tracer data (see, e.g. Carmack et al., 1997 and McLaughlin et al., 1997) is very well reproduced by the model. The results are also supported by composites of nutrient relationships from 1983-1996 which show an Atlantic dominance on the Siberian Shelves extending far eastward into the East Siberian Sea (Jones et al., 1998). The river tracer simulation shows that the Lena river represents the bulk of river water on the Canadian part of the Transpolar Drift. The Kara Sea river tracers on the other hand dominate the Siberian part of the Transpolar Drift.

Bauch et al. (1995) calculated river water fractions in the western Eurasian basin from $\mathrm{d}^{18} \mathrm{O}$ measurements and came up with values of $10-14 \%$. About two third of the Siberian river water runoff is included in the current study of $\mathrm{Ob}$, Yenisei and Lena river input. Since our fractions add up to about 9-10\% this would imply that the western Eurasian Basin river water is made up almost entirely from Siberian rivers.

\section{Transport of river contaminants by Arctic sea- ice}

In the past few years, the transport of contaminants within Arctic sea-ice became of growing concern (e.g. Pfirman et al., 1995; Meese et al., 1997; Cooper et al., 1998). In different studies (e.g. Dethleff et al., 1993; Nürnberg et al., 1994; Pfirman et al., 1997a,b; Landa et al., 1998) the Laptev and Kara Seas were identified as sources of potentially contaminated sea ice sediments. Entrainment of sediments into newly forming sea ice occurs during fall freeze up (Eicken et al., 1997) and in winter flaw leads (Dethleff et al., 1994; Dethleff et al., 1998a), which produce high amounts of new ice through the mechanism of offshore advection (e.g. Martin and Cavalieri, 1989; Dethleff et al., 1998b).

\subsection{The $\mathrm{Ob}$ and Yenisei estuaries (Kara Sea)}

Sherwood (in press) modeled the entrainment of sediments into newly forming lead ice in the southern Kara Sea off the mouths of $\mathrm{Ob}$ and Yenisej Rivers. He concluded that bottom material and riverine particles may be incorporated. Observations confirm that significantly, sediment-laden drift ice occurs in that area (pers. com. C. Haas, 1998). The sediment was considerably enriched in the upper $60-100 \mathrm{~cm}$ of the $1.5-2.0-\mathrm{m}$ thickness level and ridged ice. This points to turbulent entrainment of suspended particulate material during the initial state of ice formation in coastal flaw leads or polynyas (compare Reimnitz et al., 1993; Dethleff et al., 1998a). Turbid fast ice - with highest material concentration in the upper $30-50 \mathrm{~cm}$ of the 2 -m-thick ice canopy - was observed directly in the $\mathrm{Ob}$ Estuary. The material was probably entrained under stormy conditions during fall freeze-up and was then trapped in the coastal fast ice.

The sediment load annually discharged by the $\mathrm{Ob}$ and Yenisei into the Kara Sea is 16.5 and 5.9 million tons, respectively (Gordeev et al., 1996). Detailed export estimates of potentially radioactively polluted, ice-rafted river and shelf bottom sediments from the $\mathrm{Ob}$ and Yenisei region toward the central Arctic basin are not available due to a lack of data on local ice formation rates and sea-ice sediment concentrations. For comparison, Eicken et al. (1997) estimated 
an annual sediment export of 2-11 million tons from the Laptev Sea by ice formed during freeze-up. Dethleff (2000, submitted for publication) calculated an export of $\sim 20$ million tons. by flaw lead ice from the Laptev Sea. The total sediment export by sea ice from the Laptev Sea nearly balances the annual sediment discharge by the Lena river (Rachold et al., 1996). Mean sea-ice sediment concentrations on the Kara-, Laptev- and Beaufort shelves vary between 10 and $157 \mathrm{mg} / 1$ (e.g. Dethleff et al., 1994, $50 \mathrm{mg} / \mathrm{l}$; Dethleff et al., 1998a, $10 \mathrm{mg} / 1$; Eicken et al., 1997, $156 \mathrm{mg} / \mathrm{l}$; Lindemann, 1998, $34 \mathrm{mg} / \mathrm{l}$; Reimnitz et al., 1993, $157 \mathrm{mg} / \mathrm{l})$. Considering a mean sea-ice sediment concentration of $\sim 80 \mathrm{mg} / 1$ $\left(\sim 80 \mathrm{~g} / \mathrm{m}^{3}\right)$ derived from the above studies also for the $\mathrm{Ob}$ and Yenisei region, at least 2-3 million tons of sediment may be entrained and exported by sea ice from that area toward the Arctic basin. Combining this estimate with mean ${ }^{137} \mathrm{Cs}$ concentrations of $\sim 75 \mathrm{~Bq} / \mathrm{kg}$ detected in Kara Sea born ice sediments sampled in the central Arctic (Landa et al., 1998, see their Fig. 3) and with ${ }^{137} \mathrm{Cs}$ burdens of $30-270 \mathrm{~Bq} / \mathrm{kg}$ found in $\mathrm{Ob}$ and Yenisei bottom sediments (Stepanets et al., 1999; Miroshnikov and
Asadulin, 1999), a potential annual export of 0.1-0.8 $\mathrm{TBq}{ }^{137} \mathrm{Cs}$ can be assumed.

According to our drift simulations (Fig. 13), most of the ice formed in the $\mathrm{Ob}$ and Yenisei region is transported toward the Barents Sea. The ice melts mainly south of Svalbard (Fig. 12, Fig. 13), thereby releasing the potentially polluted sediment load. In this area, Føyn and Svaeren (1997) found accumulations of particle-bonded and biologically enriched ${ }^{137} \mathrm{Cs}$ which could not be explained by pollutions from the European reprocessing plants or the nearby sunken nuclear submarine Komsomolets. Landa et al. (1998) found a positive correlation between the clay content and the ${ }^{137} \mathrm{Cs}$ concentration in Arctic sea ice sediments. Føyn and Svaeren (1997) documented that enhanced ${ }^{137} \mathrm{Cs}$ concentrations in bottom sediments around Spitsbergen correlate also with the portion of fine fraction $(<63 \mu \mathrm{m})$ in bulk samples. Kellermann et al. (1998) report of slightly enhanced ${ }^{137} \mathrm{Cs}$ concentrations in cod fillet in the area between Spitsbergen, Bear Island and Hopen Island. From the above indications we assume that particle-bonded ${ }^{137} \mathrm{Cs}$ may be transported by drift ice from the Kara Sea toward the southern Barents Sea where melt-re-
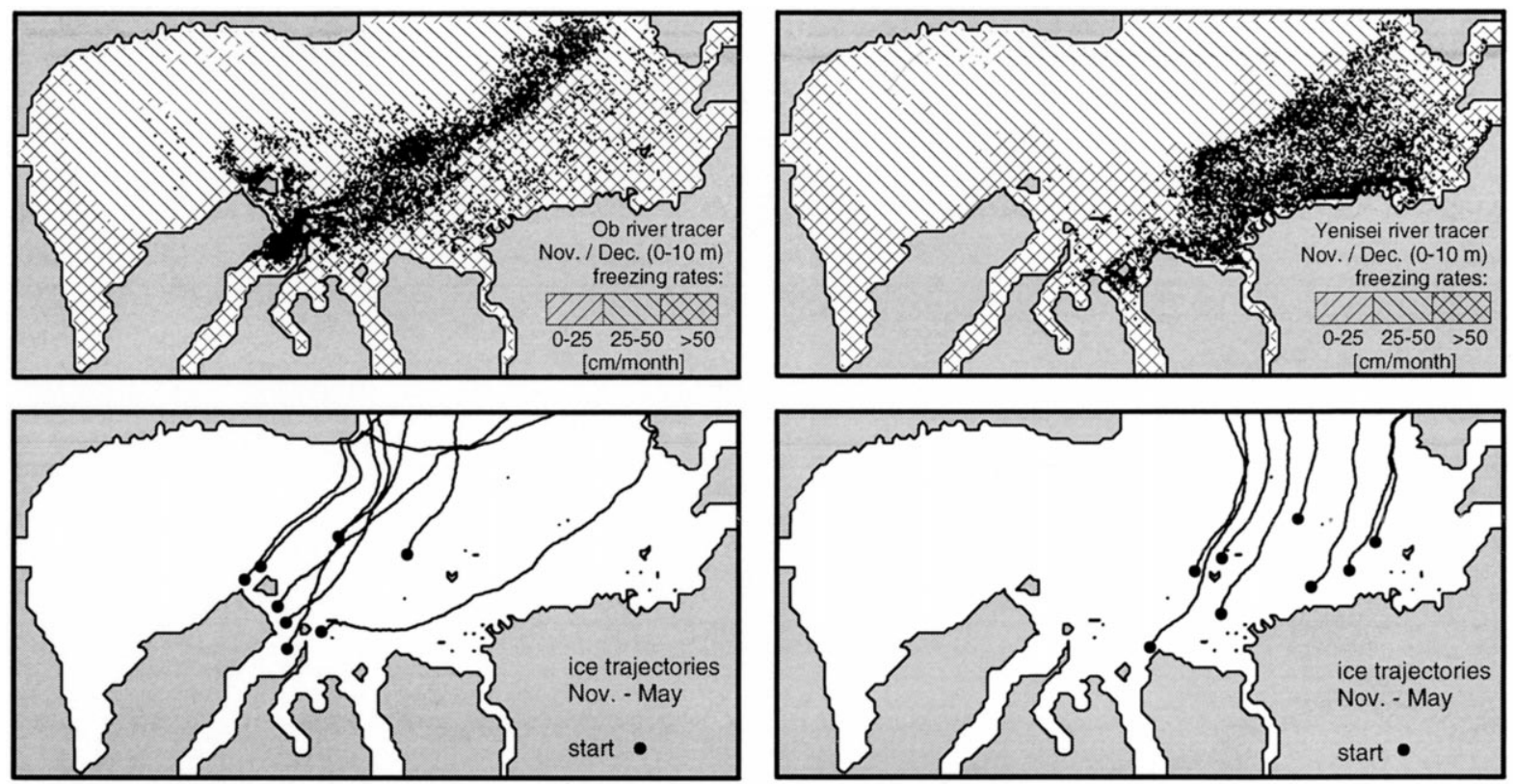

Fig. 11. Upper panels: simulated mean thermodynamic ice formation and river tracer distribution in November and December, for Ob (left) and Yenisei (right). Lower panels: simulated ice trajectories started in November in the Ob (left) and Yenisei (right) estuary. 
lease may enhance the entrainment of cesium into the local food web.

To investigate the process of particle drift with sea ice, we tried to detect at which time and in which areas the incorporation of simulated river particles into newly forming sea ice is most likely. We found that this is in November and December along the Siberian shores (Fig. 11). Off-shore winds create thin ice or open water leads where thermodynamic ice formation is larger than $50 \mathrm{~cm} /$ month (cross hatched areas). These areas coincide partly with high amounts of river tracers which emerged from $\mathrm{Ob}$ or Yenisei during previous spring (Fig. 11, upper panels). In these regions, the uptake of sediment or particles from the water column into freezing ice is very probable. Finally, we plotted Langrangian trajectories of the ice velocities from November to May in order to trace particle or sediment laden patches in

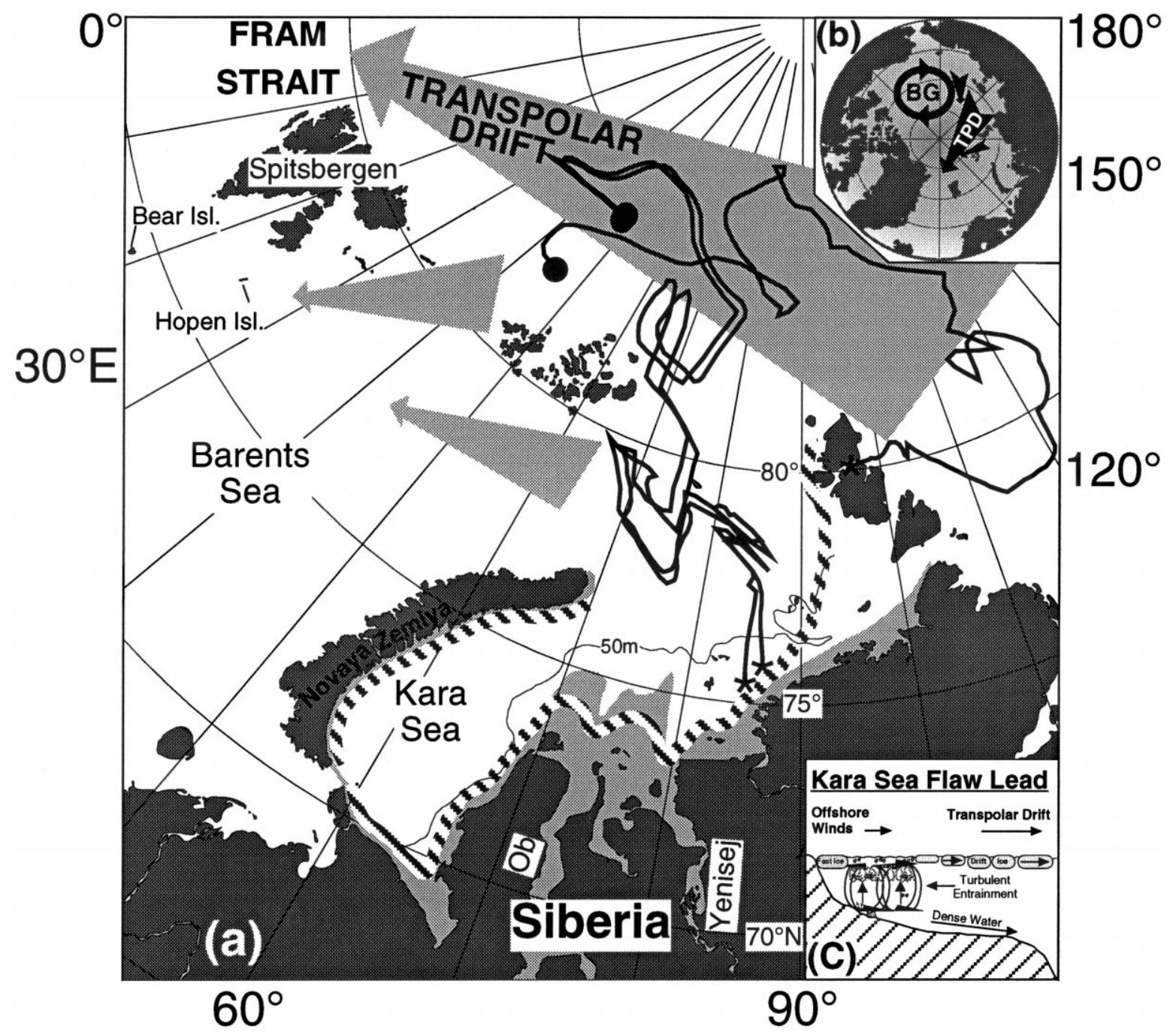

Fig. 12. Ice drift backward trajectories reworked from Landa et al. (1998) in the Kara and Laptev Seas (a). Dots denote sampling sites, asterisks represent the calculated source/starting points of the material sampled. The light grey shaded shelf fraction indicates potential shallow sediment entrainment areas $(<30-\mathrm{m}$ water depth). The hatched bold lines represent the areas of frequent flaw lead recurrence. Insets show the Transpolar Drift System (b), and cross profile of the flaw leads (c). 
newly formed sea ice (Fig. 11, lower panels). These simulations showed that, from all chosen start points, the ice trajectories are able to leave the Kara Sea within one winter. Landa et al. (1998) showed by backward trajectories that radioactively polluted sea ice sediments sampled in the Siberian Branch of the Transpolar Drift System were entrained close to the shallow sites that we chose as starting points of our forward trajectories (Fig. 12). This implies that the ice formed in the area of our investigation is supposed to leave the Kara Sea and either join the Transpolar Drift or enter the Barents Sea.

In the following, we study the large scale drift of riverine sediments incorporated into Siberian flaw lead ice. We make use of the seasonal cycle of the ice drift and ice thickness calculated by the large scale model described in Section 3.1. Ice drift trajectories are calculated for three subsequent years after being started during periods of ice formation. If the ice which carries the trajectory melts, the trajectory is stopped. An ice parcel is defined to have melted when the ice thickness sinks below $5 \mathrm{~cm}$ between May and September.

Fig. 13 shows the trajectories emanating from areas where the regional scale study has shown a high probability of the occurrence of riverine sediments at the time of freeze up. Due to the partly westward drift of particles from the Ob river (see above), we started ice drift trajectories from grid points all around the Yamal peninsula (Fig. 13a). The month of start for the $\mathrm{Ob}$ and the western Yenisei trajectories (Fig. 13b) was set to be October. Fig. 13c shows trajectories starting in the far eastern part of the Kara Sea, close to Vilkitsky Strait, where the regional scale study also has shown some probability for particles from the Yenisei to appear. Since here the freeze up commences at an earlier time, they start in September (Harms and Karcher, 1999). All three ensembles show a strong tendency to leave the Kara Sea westward into the Barents Sea. Obviously the ice parcels from the $\mathrm{Ob}$ area have a tendency to melt in the western Barents Sea at the summer ice edge. The Yenisei trajectories reach further and melt in the vicinity of Svalbard. Some of the eastern trajectories leave the shelf area north of Franz Josef Land before they also end up in the Barents Sea. The most eastern ones pass Vilkitsky Strait and join the Transpolar Drift.
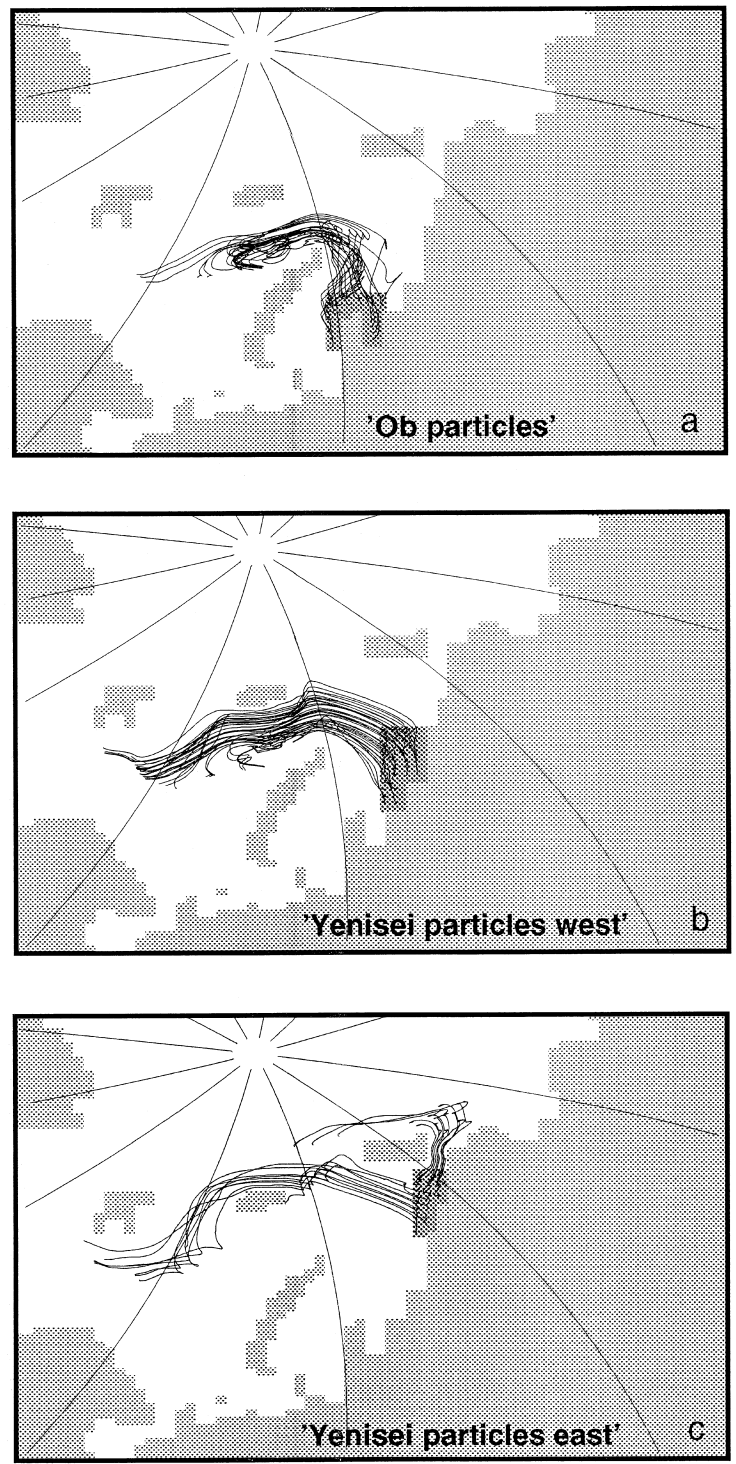

Fig. 13. Ensembles of ice drift trajectories starting in areas of likely incorporation of riverine particles in the Kara Sea. Trajectories are calculated for 3 years or until melt. The areas in dark grey show the start array; (a) Ob river particles, starting in October; (b) Yenisei river particles, western array, starting in October; (c) Yenisei particles, eastern array, starting in September.

\subsection{The Lena estuary (Laptev Sea)}

According to sedimentological investigations supported by forward and backward trajectory model results (e.g. Pfirman et al., 1997a; Landa et al., 1998), most sea ice sediments sampled in the eastern central Arctic and in Fram Strait may have been 
entrained in the Laptev Sea. Annually, between 4 and 11 million tons of sediment can be exported from the Laptev Sea through sea-ice transport i) after entrainment during fall freeze-up on extended areas of the shelf (Eicken et al., 1997), and ii) from winter flaw leads (Dethleff et al., 1994). The entrained material contributes considerably to the sediment budget of the Siberian Branch of the Transpolar Drift Ice System. After Wollenburg (1993) and Larssen et al. (1987), annually between 7 and 150 million tons of ice-incorporated clastic material may leave the Arctic Ocean through the Fram Strait towards the North Atlantic.

Fig. 14 depicts the ice trajectories which have been calculated for the starting areas where particles
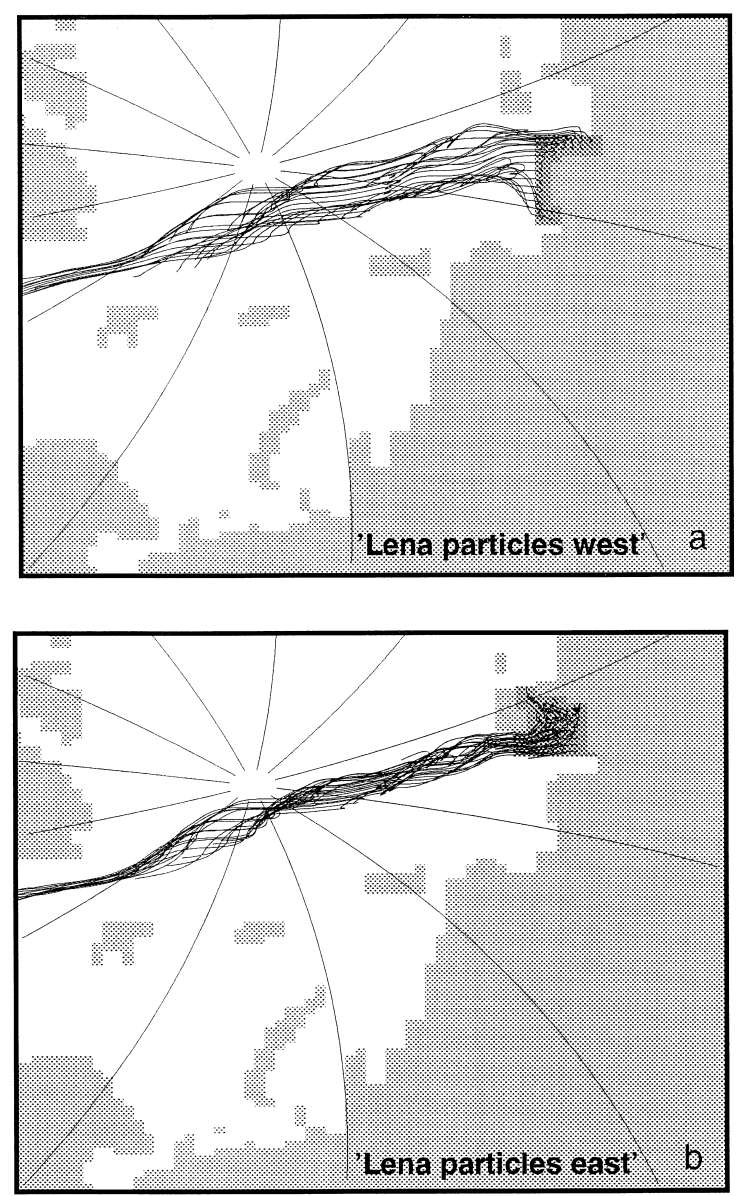

Fig. 14. As Fig. 13 but for (a) Lena river particles, western array, starting in October and (b) Lena river particles eastern array, starting in January. from the Lena river are assumed to be incorporated. The western trajectories are started in October, the eastern ones in January. All trajectories which manage to leave the Laptev Sea head forward on the Siberian flank of the Transpolar Drift to Fram Strait. This implies that the western flank of the ice drift in the East Greenland Current is likely to consist of ice from the East Siberian Sea or the Beaufort Gyre.

\section{Conclusion}

Due to the seasonally varying circulation in the Kara Sea, the dispersion of river water tracers depends very much on the time of release. During spring, the effluents from $\mathrm{Ob}$ and Yenisei propagate to a large extent into the central Kara Sea, instead of going eastward as one would expect. Main driving forces for this considerable intrusion of river water are peak discharge rates of more than $100,000 \mathrm{~m}^{3} / \mathrm{s}$ (e.g. Yenisei) and the wind. Since the spring break-up of Arctic rivers ice is a very turbulent event, large amounts of suspended load, sediments and hence contaminants might enter the Kara Sea (Pfirman et al., 1995; Krosshavn et al., 1998). Our model results confirm that together with the spring river runoff, contaminated dissolved or particulate material might spread in deep areas ( $>150-\mathrm{m}$ depth) of the Kara Sea, more than $250 \mathrm{~km}$ off the coast. However, in the remaining time of the year, mainly in autumn and winter, high amounts of river water are found mostly in very shallow areas along the Siberian shore, where a baroclinic coastal current prevails. The export of river water and, e.g. contaminants from the Kara Sea is strongest in winter, mainly through Vilkitzky Strait to the Laptev Sea. The summer export is weaker and also west of Severnaya Semlya towards the Eurasian Arctic basin. It has to be stated of course that many contaminants are not passive but, e.g. interact with the marine environment they encounter. The full range of such biogeochemical effects is far beyond the purpose of this study.

The transit times of river contaminants from $\mathrm{Ob}$ and Yenisei depend very much on the depth horizon. Whereas surface river tracers usually need less than 1 year to leave the Kara Sea, near bottom tracers might circulate for several years in the central parts. This holds in particular for the $\mathrm{Ob}$ river tracers that 
spread to a large extent in the south-western Kara Sea.

On the Arctic scale, Kara Sea river water clearly dominates in Siberian branch of the Transpolar Drift, while the Lena water dominates the Canadian branch. Due to the far western position of the Transpolar Drift, the river water fractions in Nares Strait of the Canadian Archipelago are similar to those in the northern Fram Strait. This even holds for the Kara Sea river water. As a consequence, dissolved contaminants would be able to reach the Archipelago on a time scale of 15 years after release at the Siberian estuaries. However, a change in the circulation pattern of the Arctic surface water from a far western to a more eastern position of the Transpolar Drift might interrupt a continuous feed of Siberian water into the Archipelago. Such a change is assumed to happen on time scales of 5-10 years (Proshutinsky and Johnson, 1997). This concept has to be taken into account when evaluating the oceanic state which is realised in the present model runs on the basis of a climatological forcing field.

We found strong evidence for the transport of contaminated river sediments or particles by Arctic sea ice. In the Kara Sea, the abundance of river particles in Siberian coastal waters coincides in autumn with high thermodynamic ice production rates. Very similar situations were reported from the Laptev Sea. The incorporation of river particles from $\mathrm{Ob}$, Yenisei and Lena into freezing sea ice is therefore very likely. The Arctic sea ice movement allows the incorporated particles to drift more or less undiluted towards Fram Strait, the Nordic Seas or the Barents Sea. Through ice melt, these possibly contaminated particles are introduced to the marine environment and food chain.

On the regional scale, simulated ice velocities and surface currents reveal considerable differences in direction and speed, mainly during autumn and winter along the Siberian coast. Contrary to densitydriven surface currents which tend to go eastward, the more wind-driven ice movement is mainly directed north- or north-westward into the central Arctic. The ice trajectories emerging from the $\mathrm{Ob}$ and Yenisei estuaries easily leave the Kara Sea within one winter which allows the incorporated particles to drift more or less undiluted either to the Barents Sea or towards Fram Strait. The large-scale results sug- gest that there is a high probability for ice-containing particles from Yenisei to melt in the vicinity of Svalbard. Here may be a reason for the enhanced concentrations of certain contaminants like PAHs (Klungsoyr and Stange, 1997) and PCBs (de March et al., 1998) in the surface sediment south and southeast of Svalbard.

Even if in this study no trajectory from the Kara Sea estuaries reaches Fram Strait, it has to be assumed that it is principally possible. Since we were using climatological atmospheric forcing for the numerical models, the natural variability of ice and ocean flows is underestimated. A longer period of southerly winds over the Kara Sea for example, would carry the ice a little further northward so as to reach that part of the Transpolar Drift which continues to Fram Strait. The trajectories starting from the coastal areas near the Lena river mouth show a strait forward transport with the Transpolar Drift. The finding that they make up the eastern, 'Siberian' flank of the Drift corroborate the results of backward trajectories from Pfirman et al. (1997a).

Outlooking, we can state that more field work has to be conducted in order to investigate and quantify (i) the riverine input of particulate matter and attached pollutants to the Siberian shelf seas, (ii) the rates of freeze-up and flaw lead ice formation particularly off the river mouths, and (iii) the entrainment of sediments and attached pollutant into newly forming sea ice. This holds of course also for future modelling efforts. In particular, the transport of suspended particles and sediment and the forcing of the circulation models with high-frequent, realistic meteorological data need more attention.

\section{Acknowledgements}

This work was funded by the German Ministry for Education, Research, Science and Technology (BMBF, 02-E-87054).

\section{References}

AMAP, 1998. AMAP assessment report: Arctic pollution issues. Arctic Monitoring and Assessment Programme (AMAP), Oslo, Norway, $859 \mathrm{pp}$. 
Aukrust, T., Oberhuber, J.M., 1995. Modeling of the Greenland, Iceland, and Norwegian Seas with a coupled sea ice-mixed layer-isopycnal ocean model. J. Geophys. Res. 100, 47714789.

Backhaus, J.O., 1985. A three-dimensional model for the simulation of shelf sea dynamics. Dtsch. Hydrogr. Ztg. Z. 38, H4.

Bauch, D., Schlosser, P., Fairbanks, R.G., 1995. Freshwater balance and the sources of deep and bottom waters in the Arctic Ocean inferred from the distribution of $\mathrm{H}_{2}{ }^{18} \mathrm{O}$. Prog. Oceanogr. $35,53-80$.

Carmack, E.C., Aagaard, K., Swift, J.H., MacDonald, R.W., McLaughlin, F.A., Jones, E.P., Perkin, R.G., Smith, J.N., Ellis, K.E., Kilius, L.R., 1997. Changes in temperature and tracer distributions within the Arctic Ocean: results from the 1994 Arctic Ocean section. Deep Sea Res. II 44 (8), $1487-$ 1502.

Cooper, L.W., Larsen, I.L., Beasley, T.M., Dolvin, S.S., Grebmeier, J.M., Kelley, J.M., Scott, M., Johnson-Pyrtle, A., 1998. The distribution of radiocesium and plutonium in sea ice-entrained Arctic sediments in relation to potential sources and sinks. J. Environ. Radioact. 39, 279-303.

de March, B.G.E., deWit, C.A., Muir, D.C.G., 1998. Persistent organic pollutants. AMAP Assessment Report: Arctic Pollution Issues. AMAP, Oslo, pp. 183-372.

Dethleff, D., 2000. Entrainment and export of Laptev Sea ice sediments. J. Sedimentary Res. (submitted).

Dethleff, D., Nürnberg, D., Reimnitz, E., Saarso, M., Savchenko, Y.P., 1993. East Siberian Arctic Region expedition '92: the Laptev Sea - its significance for Arctic sea-ice formation and transpolar sediment flux. Rep. Polar Res. 120, 44 pp.

Dethleff, D., Kleine, E., Loewe, P., 1994. Oceanic heat loss, sea-ice formation and sediment dynamics in a turbulent Siberian flaw lead. Proceedings of the Summer School of Physics of Ice-Covered Seas, Savonlinna, Finland. Rep. Ser. Geophys., vol. 28, Dept. of Geophysics, Univ. of Helsinki, pp. 35-40.

Dethleff, D., Loewe, P., Weiel, D., Nies, H., Kuhlmann, G., Bahe, C., Tarasov, G., 1998a. Winter expedition to the southwestern Kara Sea - investigations on formation and transport of turbid sea-ice. Rep. Polar Res. 271, 1-40.

Dethleff, D., Loewe, P., Kleine, E., 1998b. The Laptev Sea flaw lead - Detailed investigation on ice formation and export during 1991/92 winter season. Cold Reg. Sci. Technol. 27 (3), 225-243.

Eicken, H., Reimnitz, E., Alexandrov, V., Martin, T., Kassens, H., Viehoff, T., 1997. Sea-ice processes in the Laptev Sea and their importance for sediment export. Cont. Shelf Res. 17 (2), 205-233.

European Center for Medium Range Weather Forecasts (ECMWF), 1988. ECMWF Forecast Model, Physical parameterization. Res. Manual 3. 2nd edn., Reading, England.

Frank, M., 1996. Spurenstoffuntersuchungen zur Zirkulation im Eurasischen Becken des Nordpolarmeeres, Dissertation, Ruprecht-Karls-Universität, Heidelberg.

Føyn, L., Svaeren, I., 1997. Distribution and sedimentation of radionuclides in the Barents Sea. ICES J. Mar. Sci. 54, 333-340.
Gordeev, V.V., Martin, J.M., Sidorov, I.S., Sidorova, M.V., 1996. A reassessment of the Eurasian river input of water, sediment, major elements and nutrients to the Arctic ocean. Am. J. Sci. 296, 664-691.

Gorshkov, S.G., 1980. Atlas of oceans, Arctic Ocean. Military Defence Publishing House, Moscow.

Harms, I.H., 1997a. Water mass transformation in the Barents Sea. ICES J. Mar. Sci. (54).

Harms, I.H., 1997b. Modelling the dispersion of ${ }^{137} \mathrm{Cs}$ and ${ }^{239} \mathrm{Pu}$ released from dumped waste in the Kara Sea. J. Mar. Syst. 13, $1-19$.

Harms, I.H., Karcher, M.J., 1999. Modelling the seasonal variability of circulation and hydrography in the Kara Sea. J. Geophys. Res. 104, C6.

Hibler, W.D. III, 1979. A dynamic thermodynamic sea ice model. J. Phys. Oceanogr. 9.

Holland, D.M., Mysak, L.A., Oberhuber, J.M., 1996. An investigation of the general circulation of the Arctic Ocean using an isopycnal model. Tellus 48A, 138-157.

Johnson, D.R., McClimans, T.A., King, S., Grenness, Ø., 1997. Fresh water masses in the Kara Sea during summer. J. Mar. Syst. 12, 127-145.

Jones, E.P., Anderson, L.G., Swift, J.H., 1998. Distribution of Atlantic and Pacific waters in the upper Arctic Ocean: implications for circulation. Geophys. Res. Lett. 25, 765-768.

Karcher, M., Oberhuber, J.M., 1999. Modeling the ventilation of the upper and intermediate water of the Arctic Ocean with an isopycnic model. J. Geophys. Res., submitted for publication.

Kauker, F., Oberhuber, J.M., 1999. A regional version of the ocean general circulation model OPYC with open boundaries and tides. J. Geophys. Res, submitted for publication.

Kellermann, H.J., Kanisch, G., Krüger, A., Vobach, M., 1998. Radioecological studies in the Barents Sea. International Symposium on Marine Pollution, International Atomic Energy Agency (IAEA), Monaco, 5-9 October 1998, pp. 235-236.

Klungsoyr, J., Stange, K., 1997. PAHs in Barents Sea Sediments. The AMAP International Symposium on Environmental Pollution in the Arctic, Extended Abstracts, Tromso, Norway. pp. $165-167$.

Krosshavn, M., Carroll, J., Engøy, T., Grennes, Ø., Johnson, A., King, S.E., Ruud, A.B., 1998. Transport pathways of radionuclides and chemical contaminants in the Kara Sea. Radiat. Prot. Dosim. 75 (1-4), 229-236.

Landa, E., Reimnitz, E., Beals, D., Pochkowski, J., Rigor, I., 1998. Transport of ${ }^{137} \mathrm{Cs}$ and ${ }^{239,240} \mathrm{Pu}$ by ice rafted debris in the Arctic Ocean. Arctic 51 (1), 27-39.

Larssen, B.B., Elverhøi, A., Aagaard, P., 1987. Study of particulate material in sea ice in the Fram Strait - a contribution to paleoclimate research. Polar Res. 5 (3), 313-315.

Levitus, S., 1982. Climatological atlas of the world ocean. NOAA Prof. Pap. 13, Rockville, Md., USA.

Lindemann, F., 1998. Sediments in arctic sea ice — entrainment, characterization and quantification. Rep. Polar Res. 283, 1-123 (in German).

Martin, S., Cavalieri, D.J., 1989. Contributions of the Siberian Shelf polynyas to the Arctic Ocean intermediate and deep water. J. Geophys. Res. 94 (C9), 12,725-12,738. 
Maykut, G.A., 1986. The surface heat and mass balance. In: Untersteiner, N. (Ed.), Geophysics of Sea Ice. NATO ASI Ser., Ser. B, vol. 146, Plenum, New York.

McClimans, T.A., 1997. Model verification of transport processes in the Barents and Kara Seas. The AMAP International Symposium on Environmental Pollution of the Arctic, 1-5. June 1997, Troms $\varnothing$, Norway, extended abstract volume.

McLaughlin, F.A., Carmack, E.C., Macdonald, R.W., Bishop, J.K.B., 1997. Physical and geochemical properties across the Atlantic/Pacific water mass front in the southern Canadian basin. J. Geophys. Res. 101, 1183-1197.

Meese, D.A., Reimnitz, E., Tucker, W.B. III, Gow, A.J., Bischof, J., Darby, D., 1997. Evidence for radionuclide transport by sea-ice. Sci. Total Environ. 202, 267-278.

Milligan, D., 1969. Oceanographic survey results: Kara Sea, summer and fall 1965. Technical report, U.S. Naval Oceanographic Office, Washington D.C., TR-217.

Miroshnikov, A.Y., Asadulin, A.A., 1999. Tracking and distribution of radioactive contamination from nuclear plants to the bottom sediments of the $\mathrm{Ob}$ and Yenisei rivers and the Kara Sea Basin. In: Matthiessen, J., Stepanets, O.V., Stein, R., Fütterer, D.K., Galimov, E.M. (Eds.), The Kara Sea Expedition of RV Akademik Boris Petrov 1997: First Results of a Joint Russian-German Pilot Study. Rep. Polar Res., vol. 300, pp. $145-153$.

Nansen, F., 1902. Oceanography of the North Polar Basin. In: Nansen, F. (Ed.), The Norwegian North Polar Expedition 1893-1896, Scientific Results, vol. III, 427 pp.

NATO, 1998. NATO/CCMS Pilot Study: Cross-Border Environmental Problems Emanating from Defence-related Installations and Activities, Phase II: 1995-1998, Final Report, Volume 2: Radioactive Contamination of Rivers and Transport through Rivers, Deltas and Estuaries to the Sea, Report No. 225.

Nürnberg, D., Wollenburg, I., Dethleff, D., Eicken, H., Kassens, H., Letzig, T., Reimnitz, E., Thiede, J., 1994. Sediments in Arctic sea ice - entrainment, transport and release. Mar. Geol. 119, 185-214.

Oberhuber, J.M., 1993. Simulation of the Atlantic Circulation with a coupled sea ice-mixed layer-isopycnal general circulation model: Part I. Model description. J. Phys. Oceanogr. 23, 808-829.

Olsson, K., Anderson, L.G., 1997. Input and biogeochemical transformation of dissolved carbon in the Siberian shelf seas. Cont. Shelf Res. 17 (7), 819-833.

Parkinson, C.L., Washington, W.M., 1979. A large scale numerical model of sea ice. J. Geophys. Res. 84 (C1), 311-337.

Pavlov, V.K., Kulakov, M.Y. and Stanovoy, V., 1993. Oceanographical Description of the Kara and Barents Sea. Report to the IASAP, IAEA, Vienna, Austria.

Pavlov, V.K., Pfirman, S.L., 1995. Hydrographic structure and variability of the Kara Sea: implications for pollutant distribution. Deep Sea Res. 42 (6).

Pfirman, S., Eicken, H., Bauch, D., Weeks, W.F., 1995. The potential transport of pollutants by Arctic sea ice. Sci. Total Environ. 159, 129-146.

Pfirman, S., Colony, R., Nürnberg, D., Eicken, H., Rigor, I., 1997a. Reconstructing the origin and trajectory of drifting Arctic sea-ice. J. Geophys. Res. 102 (C6), 12,575-12,586.

Pfirman, S., Kögele, J.W., Rigor, I., 1997b. Potential for rapid transport of contaminants from the Kara Sea. Sci. Total Environ. 202, 111-122.

Proshutinsky, A.Y., Johnson, M.A., 1997. Two circulation regimes of the wind-driven Arctic Ocean. J. Geophys. Res. 102, 12,493-12,514.

Rachold, V., Alabyan, A., Hubberten, H.-W., Korotaev, V.N., Zaitsev, A.A., 1996. Sediment transport to the Laptev Sea hydrology and geochemistry of the Lena River. Polar Res. 15, 183-196.

Reimnitz, E., McCormick, M., McDougall, K., Brouwers, E., 1993. Sediment-export by ice rafting from a coastal polynya, Arctic Alaska. Arct. Alp. Res. 25 (2), 83-98.

Schlosser, P., Swift, J.H., Lewis, D., Pfirman, S.L., 1995. The role of the large-scale Arctic Ocean circulation in the transport of contaminants. Deep Sea Res. II 42, 1341-1367.

Semtner, A.J., 1976. A model for the thermodynamic growth of sea ice in numerical investigations of climate. J. Phys. Oceanogr. 6, 379-389.

Sherwood, C. Numerical model of frazil-ice and suspended-sediment concentrations, and formation of sediment-laden ice in the Kara Sea. J. Geophys. Res., in press.

Stein, R. (Ed.), 1989. Arctic Paleo-River Discharge (APARD), A New Research Programme of the Arctic Ocean Science Board (AOSB). Reports on Polar Research, Alfred Wegener Institute for Polar and Marine Research, Bremerhaven, Germany, no. 279, $128 \mathrm{pp}$.

Stepanets, O.V., Borisov, A.P., Solov'eva, G.Yu., 1999. Distribution of anthropogenic radionuclides in the estuaries of $\mathrm{Ob}$ and Yenisei rivers and adjacent Kara Sea. In: Matthiessen, J., Stepanets, O.V., Stein, R., Fütterer, D.K., Galimov, E.M. (Eds.), The Kara Sea Expedition of RV Akademik Boris Petrov 1997: First Results of a Joint Russian-German Pilot Study. Rep. Polar Res., vol. 300, pp. 132-140.

Stronach, J.A., Backhaus, J.O., Murty, T.S., 1993. An update on the numerical simulation of oceanographic processes in the waters between Vancouver Island and the mainland: the GF8 model. Oceanogr. Mar. Biol. Ann. Rev. (31), UCL press.

Trenberth, K.E., Olson, J.G. and Large, W.G., 1989. A global ocean wind stress climatology based on ECMWF analyses, NCAR Tech. Note NCAR/TN-338+STR, 93 pp.

Wollenburg, I., 1993. Sedimenttransport durch das arktische Meereis: die rezente lithogene und biogene Materialfracht. Berichte zur Polarforschung (Rep. Polar Res.) 127, 1-159.

Wright, P., 1988. An atlas based on the COADS data set: fields of mean wind, cloudiness and humidity at the surface of the global ocean. Techn. Rep. 14, Max-Planck-Institut für Meteorologie, Hamburg, Germany. 